María E. Bordagaray, La dimensión biográfica en la configuración de los colectivos libertarios en Argentina / The biographical dimension in shaping libertarian collective in Argentina (1920-1950), Revista Izquierdas, 27, abril 2016, ISSN 0718-5049, pp. 32-62

\title{
La dimensión biográfica en la configuración de los colectivos libertarios en Argentina*
}

The biographical dimension in shaping libertarian collective in Argentina (1920-1950)

\author{
María Eugenia Bordagaray $^{* *}$
}

\footnotetext{
* El presente trabajo forma parte de mi tesis doctoral titulada "Controversias libertarias: la interpelación anarquista en tiempos del peronismo". Bajo la dirección de la Dra. Adriana Valobra, la investigación fue financiada por CONICET, por medio de becas de formación doctoral entre los años 2009 y 2014.

** Profesora de Historia (FAHCE-UNLP). Doctora en Historia(FAHCE-UNLP). Miembro del Instituto de Investigaciones en Humanidades y Ciencias Sociales (IDIHCS), UNLP-CONICET. Correo electrónico: eugebordagaray@yahoo.com.ar Agradezco la colaboración de Ana Russo por sus aportes en la traducción del resumen y las palabras clave.
} 


\section{Resumen:}

El presente trabajo aborda las biografías de militantes que participan en los colectivos libertarios entre la década del 20 y mediados de siglo XX. Partiendo de las propuestas metodológicas de la sociología de la crítica, desde los postulados de Bernard Lahire, este abordaje pretende visibilizar experiencias, identidades, vidas y experiencias de participación política de algunos de los y las referentes del anarquismo en la Argentina: José Grunfeld, Juan Lazarte, José María Lunazzi, Jacobo Maguid, Herminia Brumana, Iris Pavón y Ana Piacenza. Por otro lado, la perspectiva de género nos permitirá vislumbrar las trayectorias diferenciadas de hombres y mujeres como estrategias performativas del "ser" y de concebir la acción política anarquista.

Palabras clave: Biografías-AnarquismoTrayectorias-Colectivos-Género

Recibido: 21 octubre 2015

Aceptado: 17 enero 2016

\begin{abstract}
:
This paper addresses the biographies of militants involved in the libertarian collectives from the 20s to mid-twentieth century. Based on the methodological approaches of sociology of criticism, from the postulates of Bernard Lahire, this approach aims to make visible experiences, identities, lives and experiences of political participation and some of the references of anarchism in Argentina: Jose Grunfeld, Juan Lazarte, José María Lunazzi, Jacobo Magid, Herminia Brumana, Iris Pavon and Ana Piacenza. On the other hand, the gender perspective allows us to observe the different paths of men and women as performative strategies of "being" and anarchist conception of political action.
\end{abstract}

Keywords: Biographys- Anarchism- TrayectoryGroups- Gender

\section{Introducción}

La historia del anarquismo en Argentina ha concitado especial atención de quienes investigan y ello es especialmente cierto para la etapa que corre entre fines del siglo XIX y las dos primeras décadas del 20, que ha sido visualizada como la de esplendor del colectivo libertario. La cita que encabeza el presente capítulo nos coloca frente a la prevalencia de este recorte temporal en investigaciones recientes sobre el anarquismo. Historiar al anarquismo y su trayectoria en el movimiento obrero entre 1890 y 1930, había sido, hasta no hace mucho tiempo atrás, objeto de la atención de algunos intelectuales anarquistas. Podemos pensar en los casos de Diego Abad de Santillan y Sebastián Marotta, entre muchos otros. (Abad de Santillán, 1930; Marotta , 1960) Esta "historia" desde adentro aporta fundamentalmente información detallada, un gran corpus documental, pero puede adolecer de "sentido crítico" en relación al elemento político en el que actúan y al que historizan. (Camarero, 2005) Pero las motivaciones de estas escrituras no se agotan en el sentido reivindicativo de los movimientos políticos o sindicales a los que pertenecen. Debe considerarse también que fueron herramientas de acción política con las que estos militantes, dedicados al trabajo intelectual a la vez que comprometidos con su tiempo y sus ideas, intervienen en la arena política, con las cuales entran en discusión con el Estado, la sociedad civil y el resto de las tendencias políticas. 
María E. Bordagaray, La dimensión biográfica en la configuración de los colectivos libertarios en Argentina / The biographical dimension in shaping libertarian collective in Argentina (1920-1950), Revista Izquierdas, 27, abril 2016, ISSN 0718-5049, pp. 32-62

Dentro del grupo de estudios renovadores de la temática anarquista, Zaragoza Rovira (1996) y Capelletti (1990), también ven un quiebre y la decadencia del anarquismo en los mismos años que los estudios que anteceden. Juan Suriano (2001) destaca la difusión de las ideas libertarias en ámbitos no exclusivamente obreros, delimitando las distancias entre bases y vanguardias del movimiento, así como recalando en las particularidades de la praxis anarquista a través de sus diarios, publicaciones, proyectos educativos y reuniones culturales en las que el ideario ácrata parece haberse plasmado, paralelamente a la labor sindical en los primero años del Siglo XX. Sin embargo, cita su decadencia apenas comenzada la década del 10'.

Pero las investigaciones han sido más parcas sobre el desarrollo del anarquismo durante la década del '30, en el supuesto de que sus militantes fueron brutalmente reprimidos por el primer gobierno de facto en Argentina. La deportación, cárcel y asesinato de los militantes habría silenciado las prácticas ácratas. Estas investigaciones acuerdan también que existió una imposibilidad de conciliar intereses que entre las diversas tendencias del anarquismo en el Río de la Plata. Particularmente, se ha enfocado la discusión en torno a la incongruencia político-ideológica que implicaba crear una organización entre quienes se oponen a cualquier tipo de determinación orgánica para sus acciones y las dificultades para sostener el ideario ácrata en el escenario político y social pos golpe de 1930. Como bien indica Omar Acha (2009), estas interpretaciones creen que el problema del anarquismo (...) reside en el diseño de una estrategia inadecuada para una sociedad en proceso de modernización y democratización”. (Acha, 2009: 95) De este modo, la Ley Sáenz Peña y la consecuente participación política popular a través de la presidencia de Irigoyen, la aparición de una cultura de masas, así como también ciertas mejoras en las condiciones económicas y laborales de los trabajadores habrían obturado la capacidad del movimiento libertario para hacerse eco de nuevas problemáticas que los interpelen, ya no ligadas a la mejora de la calidad de vida por vías revolucionarias. ${ }^{1}$

Retomar el estudio del anarquismo desde una perspectiva biográfica implica reconocer estos antecedentes al mismo tiempo se profundiza en nuevas dimensiones con la posibilidad de enriquecer el debate historiográfico. Las biografías anarquistas, las escritas y publicadas o aquellas que solo persisten en las memorias de antiguos y nuevos militantes libertarios, se encuentran rodeadas por un halo de heroicidad. En general, las acciones públicas y políticas son puestas de relieve y obnubilan los aspectos de sus vidas familiares, las desavenencias económicas, la relación con sus compañeros, o sus trayectos laborales. Estas interpretaciones se han instalado en el imaginario popular y en el sentido común historiográfico. Por otro lado, aquellos abordajes que rescatan sus historias de vida, focalizan las experiencias personales que alimentan la figura heroica, como por ejemplo el

\footnotetext{
${ }^{1}$ Luciana Anapios (2011) interpreta bajo esta perspectiva el quiebre del anarquismo tal como se lo conoce hasta la década del 20: "el lugar preponderante del anarquismo iban a cambiar lentamente durante la segunda década del siglo XX. A esto contribuyeron tanto la represión al movimiento a partir del Centenario de 1910, como las transformaciones en el sistema político y en la sociedad civil tras la reforma electoral y los sucesivos gobiernos radicales (...) se sumó la irrupción de la cultura de masas, con la radio, el cine, el fútbol y una industria editorial variada que competía con la cultura de izquierda por el mismo público lector. (...) Durante la segunda mitad de la década, frente al declive de su influencia en el movimiento obrero y el alejamiento de algunos militantes e intelectuales, las querellas internas se multiplicaron (...)." (Anapios, 2011: s/d)
} 
María E. Bordagaray, La dimensión biográfica en la configuración de los colectivos libertarios en Argentina / The biographical dimension in shaping libertarian collective in Argentina (1920-1950), Revista Izquierdas, 27, abril 2016, ISSN 0718-5049, pp. 32-62

de la huida con un o una amante, las extravagancias en sus vidas cotidianas, la relaciones con personas de otras clases sociales o de ideas políticas diversas. Del mismo modo, los relatos están marcados por los modelos de género, del militante masculino y de las acciones de las mujeres que se salen de "la regla". Sin duda, el mito del "héroe" (masculino) está presente en todas sus representaciones, cuestión que se refuerza con la misma simbología e ideología propia del anarquismo:

La militancia en el anarquismo estuvo siempre enmarcada en un nivel de compromiso e idealismo tan fuertes que en más de una ocasión generó admiración y simpatía por parte de individuos y grupos que nada tenían ni tienen que ver con la lucha que esa militancia sostiene. Y es que los Héroes Míticos del anarquismo reproducen el mito del Héroe, tan afecto para nuestra cultura Occidental y Cristiana. (Hernún, 2003: s/d)

Los relatos biográficos sobre Simón Radowitzki o Severino Di Giovani, caracterizados por Bayer a partir de su pertenencia al grupo de los "anarquistas expropiadores", realzan en general el carácter abnegado, militante y heroico del personaje junto a otros como Wilckens, Rocigna y las mujeres que acompañan a los héroes (Marti, 2010; Bayer, 2007). Es el caso de América Scarffó: hija hermana y amante de anarquistas o el de la esposa de Vuotto uno de los presos de Bragado. ${ }^{2}$ Con respecto a las mujeres anarquistas, Salvadora Medina Onrubia es la referencia inevitable de los estudios que abordan el anarquismo que se emparenta con el feminismo. Los abordajes sobre su vida van desde adjudicarle una adscripción anarco-feminista combativa, prístina y única hasta el de ejemplo de mujer intelectual "burguesa" con simpatías hacia la cuestión social y las ideas libertarias. (Guzzo, 2014; Saitta, 1995)

Otra referencia inevitable cuando hablamos de biografías de militantes políticos, son las autobiografías. Sin la escrita por Juana Rouco Buela, seguramente la referencia de su accionar en pos de lo que ella denominó "la idea", hubiera quedado olvidada. Entre los hombres, Jose Grunfeld o Jacobo Maguid tienen la misma preocupación que Rouco Buela: explicar sus vidas en relación con la historia del anarquismo. En ambos casos, las autobiografías permiten captar los sucesos personales, las experiencias individuales, familiares y laborales como elementos de una cadencia que marcan el itinerario posible de las acciones en sus vidas militantes. Sin embargo, no olvidamos que en el mismo acto de escritura, estos sujetos elaboran una estrategia argumentativa en la cual la dimensión política y polémica se enlazan con el acto confesional e introspectivo en el relato (Miraux, 2015). Reivindican sus propias acciones en torno a la militancia por sus ideales mientras que el ordenamiento cronológico de los hechos no responde exactamente a un orden

\footnotetext{
${ }^{2}$ El encarcelamiento de tres obreros de orientación anarquista Pascual Vuotto, Santiago Mainini y Reclús De Diago, en 1931, acusados de un atentado en el que murieron la hija y la cuñada de José María Blanch (personaje político aliado al conservadurismo de la ciudad de Bragado), produce el inmediato repudio de todo el arco opositor al gobierno de facto y sus sectores aliados y se organizan los comités de ayuda a los llamados a partir de ese momento "presos de Bragado". (Bordagaray, 2013). Donatila Barrera fue una militante anarquista que alcanza relevancia anecdótica y romántica ya que, siendo compañera del militante ácrata Danton Ludueña, se enamoró de Pascual Vuotto, uno de los presos durante el proceso de Bragado (Guzzo, 2014).
} 
sucesivo, sino más bien a la autorreferencialidad con respecto a la posición y el lugar ocupado en momentos históricos relevantes. ${ }^{3}$

En general los abordajes biográficos que parten de los estudios sociales consideran únicamente, según Lahire,

(...) algunos desplazamientos importantes en el espacio social, en términos de volumen y de estructura de distribución de capital poseído (caso de declives sociales o de gran movilidad social ascendente), se acaba por olvidar que también existen desplazamientos y o cambios en el universo familiar (convertirse en padre, divorciarse si estaba casado...) en el universo de amistad, etc., lo mismo que en el orden socioprofesional (...) (Lahire, 2004: 72)

Nuestro objetivo, al abordar las biografías, no es el de enumerar las características del colectivo anarquista a partir de la suma de las individualidades de sus sostenedores sino, mas bien, explicar la heterogeneidad de las experiencias de quienes se movilizaron políticamente tras la bandera anarquista entre los años que la historiografía clásica ha definido como de "crisis y desaparición" del anarquismo argentino. Esto es, la de quienes abrazan la cauda anarquista a partir de la década del 30 y sostienen su militancia y compromiso al menos, hasta finalizados los años 50.

Sin duda, en tiempos en que el anarquismo pierde la masividad del apoyo entre los sectores populares, las individualidades de quienes organizan y sostienen el movimiento tiene un lugar primordial para explicar su historia. ${ }^{4}$ Pero la vida de quienes abrazaron la causa anarquista, no comienza ni acaba en sus experiencias de acción política y/ o pública. Es allí, en la diversidad de las experiencias, marcadas por su origen social y de género, en donde veremos desplegar sus biografías.

De este modo, seguimos los planteos de Lahire, para quien las condiciones sociales (materiales, estructurales) "antes que dar por supuesta la sistemática influencia del pasado sobre el presente (...) presiona en todo momento sobre todas nuestras situaciones vividas (...), las biografías deben pensarse como el

desencadenamiento de los esquemas de acción incorporadas (producidos en el curso del conjunto de las experiencias pasadas) por los elementos o por la configuración de la situación presente (...), las maneras con que una parte de las experiencias pasadas incorporadas es movilizada, convocada, despertada por la situación presente. (Lahire, 2004: 77)

Estas marcas de origen son la arena en la que creemos se despliegan las estrategias individuales conscientes y no conscientes, racionales y no racionales, por interés, por estrategias, por amor.

Resta una pequeña referencia acerca de aquellas personas referentes del anarquismo que abordaremos en su individualidad: Jacobo Maguid, Jose Grunfeld, Juan Lazarte, José

\footnotetext{
${ }^{3}$ Sobre las autobiografías, nos remitimos al trabajo de Miraux (2005).

${ }^{4}$ La especificidad de la apelación y la interpelación anarquista en los años que van de 1935 a 1955, ha sido abordada en Bordagaray (2011 b) y Bordagaray (2014)
} 
María Lunazzi, Herminia Brumana, Iris Pavón y Ana Piacenza. Nuestra elección como integrantes del movimiento libertario no ha sido casual. Responde, en primer lugar, a la importancia que el mismo movimiento les ha atribuido como organizadores/as y propagandistas del anarquismo a partir de 1930 y como principales sostenedores del antifascismo en clave libertaria. En segundo lugar, pero no menos importante, estas mismas personas (fundamentalmente los varones) han sido y son permanentemente referidos como vértebras fundamentales de la columna anarquista a lo largo de casi todo el siglo XX tanto en la prensa escrita como entre los mismos militantes del movimiento libertario. Por último, se rescatan trayectorias que evidencian que las luchas políticas fueron de la mano de una vida amorosa y familiar compartida. Abordar a estos/as sujetos/as permitirá visibilizar una parte importante de sus biografías y comprender sus aportes al ideario y el movimiento anarquista en el compromiso conjunto y en el diálogo cotidiano así como también, nos permitirá captar cierta configuración subjetivo- identitaria que la militancia compartida pudo haber agregado a sus posicionamientos.

Es necesaria, también, una breve mención acerca de aquellos/aquellas que no abordaremos en el presente capítulo y que se nos presentan como referentes ineludibles en nuestra historia: Diego Abad de Santillán (De la Rosa, 2012) como así también Salvadora Medina Onrrubia (Barrandeguy, 1997; Delgado, 2007; Saitta, 2006, Guzzo, 2003). En primer lugar, nuestro interés con el presente trabajo reside principalmente en visibilizar a quienes cumplieron un rol preponderante en la organización del movimiento libertario pero cuyas acciones no han sido recuperadas ni por la historiografía y acaso tampoco por las memorias militantes.

Metodológicamente, intentaremos realizar un abordaje colectivo-biográfico, siguiendo los lineamientos de las biografía según a Lahire y la sociología de la crítica. ${ }^{5} \mathrm{Si}$ bien muchos de los datos biográficos (fecha y lugar de nacimiento, matrimonio, hijos, principales acontecimientos) con los que abordaremos esta investigación ya han sido expuestos en muchos trabajos, nos interesa recuperarlos para reconstruir las biografías militantes de manera colectiva en cuanto a que la referencia a seguir en cada uno de los caminos, son sus acciones en relación a los ideales que los movilizan. Para ello, hemos seleccionado algunos ítems a partir de los cuales ordenaremos algunos datos y construiremos otros sobre las y los sujetos actuantes.

\section{Inmigración y sociabilidades}

Las narraciones historiográficas sobre la historia del anarquismo en la Argentina, refieren en general a estos orígenes europeos descriptos por Oved.

Dentro de esa ola migratoria, que atrajo campesinos, obreros y miembros de la baja clase media, se encontraban comprensiblemente muchos activistas de las federaciones obreras españolas. Estos activistas, que llegaron a la Argentina como

\footnotetext{
${ }^{5}$ Retomamos la cuestión "colectiva" de las biografías en cuanto a algunos itinerarios que creemos comunes pero mayoritariamente diversos. Es por ello que nuestra apuesta se diferencia de la mirada que sobre las biografías colectivas han primado en la historia social o en la historia intelectual, en las cuales ha primado la de Bourdieu (2005)
}

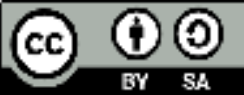


María E. Bordagaray, La dimensión biográfica en la configuración de los colectivos libertarios en Argentina / The biographical dimension in shaping libertarian collective in Argentina (1920-1950), Revista Izquierdas, 27, abril 2016, ISSN 0718-5049, pp. 32-62

emigrantes por motivos económicos o como exiliados políticos, trajeron consigo la ideología y sus posiciones en las controversias ideológicas, así como las tradiciones que habían consolidado en su patria. Hubo muchos que cambiaron su estilo de vida, su status (aldeanos se convirtieron en urbanos) y también sus enfoques, después de su traslado a un país nuevo y a nuevas condiciones. (...) Pero muchos otros buscaron el camino para renovar su actividad anarquista en la Argentina". (Oved, 1991: s/n)

Del mismo modo, la historiografía, ha manifestado que el movimiento anarquista en los últimos años del Siglo XIX y principios del XX floreció y se sostuvo fundamentalmente entre inmigrantes, europeos, que se instalan en los crecientes pueblos y ciudades rioplatenses. La mayoría de estos inmigrantes eran hombres jóvenes, solteros y contaban sólo con la referencia de algún paisano o familiar lejano para elegir su destino en las pampas argentinas (Devoto, 2003; Bjerg, 2009). Las ideas políticas acompañan, en paralelo a este proceso de movilidad, de traslado y de llegada de inmigrantes en búsqueda de posibilidades de ascenso social por medio de una mejor posición económica. Otros, venían expulsados por su actividad política en sus países de origen (Cesano, 2010). Si bien estadísticamente se habla de una preeminencia de la inmigración italiana hasta 1914, en relación al mundo de las ideas y puntualmente a los grupos anarquistas, "(...) el anarquismo argentino se desarrolló a la zaga del de España y estaba sujeto a la influencia de los militantes y las ideas originadas en la península". (Oved, 1991: s/n) Estas apreciaciones son las que han estructurado la historia de las ideas y de la historia social en la Argentina. Es decir, partiendo de identificar las zonas de origen o de gestación de determinadas configuraciones ideológicas y políticas, sería posible rastrear los derroteros de quienes adhirieron y promulgaron esas mismas ideas en otros territorios y otros tiempos. (Oved, 1991; Bayer, 2007) Sin embargo, y sin desconocer estas miradas e interpretaciones de la historia del anarquismo y la inmigración en nuestro país, los inicios de nuestra historia se ubican en un lugar levemente desplazado de este eje. Comprendemos las configuraciones identitarias como mecanismos complejos, en constante proceso de reformulación y siempre provisorios, al mismo tiempo histórica y geográficamente situados. (Latour, 2008)

Esta introducción al problema resulta de fundamental importancia puesto que la totalidad de las biografías que hemos seleccionado se inscribe dentro de esa historia general de la inmigración: son hijos de inmigrantes, nacidos en Argentina o llegados de niños desde Europa del Este, España e Italia. Pero su procedencia europea no se relaciona directamente con la comunión en las ideas anarquistas. Más bien, los orígenes familiares de estos militantes hablan de experiencias de sociabilidad en una amplia cultura política, republicana, de izquierdas, cercanas al socialismo, pero que se manifiesta en un hogar en el que se apuesta a la lectura y la formación política autodidacta como una práctica cotidiana.

Durante la guerra ruso japonesa (1904-1905), los padres de Jacobo Maguid huyen de la persecución que sufren los judíos en la Rusia de los zares. Se instalan en la ciudad de Santa Fe:

Mi padre obrero y mi incansable madre para sus ocho hijos, aman la lectura y la comentan. No se conforman con el diario porteño <Idische Tzaitung>, sino que reciben el semanario Idische Gazete desde los Estados Unidos. En un cajón tienen libros variados. (Jacinto Cimazo, 1995: 21)

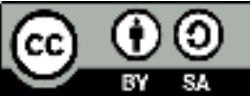


Segundo en una familia de 8 hijos, Jacobo Maguid narra de esta manera, en su autobiografía, parte de sus registros de la infancia. ${ }^{6}$ Denota la relación estrecha entre su familia y sus orígenes judíos europeos a través de la lectura de los periódicos en idioma idish locales e internacionales. En otro pasaje de su autobiografía relata una sociabilidad que, fundada en las prácticas religiosas del judaísmo, relaciona a esta familia humilde con otras provenientes del "centro de la ciudad", sectores comerciantes con una posición más acomodada:

En la víspera de Iom Kipur, nos emociona el rezo de Jaezan y la conmovedora melodía del Kol Nidrej con alaba al altísimo. Pero antes, los chicos vemos que el patio se llena de gente frente a mesas preparadas para recibir contribuciones en dinero para instituciones benéficas de la colectividad. (...) En ese único Día del Perdón aparecen caras conocidas o nuevas de los que constituyen la clase privilegiada: tenderos, muebleros, negociantes (...). (Jacinto Cimazo, 1995: 13)

Del mismo modo, José Grunfeld relata en sus memorias el prestigio que contaba su padre entre los sectores más prominentes de Moisés Ville, una de las colonias judías más antiguas e importantes de las creadas en territorio argentino. Ese prestigio no se relaciona con su posición económica, ya que son una familia numerosa que vive del trabajo en tareas rurales y de la explotación de una parcela en la colonia del Barón de Hirsch. Su prestigio se apoyaba en sus valores "morales" y en haber sido reconocido como un hombre culto y comprometido con los valores de la comunidad (Grunfeld, 2000). La familia Grunfeld/Grinfeld, originaria de Berasavia, de orígenes humildes como la de Maguid, se instala en la colonia judía santafesina también en los primeros años del Siglo XX. ${ }^{7}$ Los hermanos José, Rafael y David transitarán juntos no solamente su infancia en el pueblo, sino el viaje a la ciudad y la participación en el movimiento anarquista. ${ }^{8}$ Reciben educación primaria en la colonia, donde la religión era una parte fundamental en la formación de los niños.

Resulta interesante introducir aquí una cuestión que, si bien por lo pronto sólo será enunciada, puede ayudar a comprender la particularidad de algunas trayectorias biográficas que tienen sus orígenes en las familias judías y por lo cual su adscripción étnica resultará relevante en tiempos de acción política en el anarquismo. Pensando en las comunidades de principios del siglo XX, Falcón asegura que

\footnotetext{
${ }^{6}$ Horacio Tarcus ha recopilado la totalidad de los seudónimos empleados por Maguid en su vida estudiantil y como militante organizador del anarquismo en sus constantes intervenciones por medio de la escritura en la prensa orgánica: Macizo, Jacinto Cimazo, Floreal O. Pina, Víctor Guidmá, Jorge Niero, Edgar Balpervi, M. Acizo. (Tarcus, 2007)

${ }^{7}$ Carlos José Rocca (1998) asegura que los Grunfeld provienen de Kishinev, capital de Moldavia. Nosotros nos apoyamos en la información brindada por Grunfeld en su autobiografía (Grunfled, 2000)

${ }^{8}$ En su biografía, Rocca destaca que José Grunfeld trabajó en distintas ocupaciones en su adolescencia en Ceres, Rosario y La Plata. Diferente a sus hermanos David y Rafael que realizan estudios universitarios y logran reconocimiento internacional en sus especialidades: Rafael como físico y David como médico cardiólogo. Rocca, Carlos José (1998). José María Lunazzi. Semblanza de un Socialista Libertario. Editorial Universitaria de LA Plata
} 
María E. Bordagaray, La dimensión biográfica en la configuración de los colectivos libertarios en Argentina / The biographical dimension in shaping libertarian collective in Argentina (1920-1950), Revista Izquierdas, 27, abril 2016, ISSN 0718-5049, pp. 32-62

(...) los anarquistas adoptarán el principio de la organización de grupos sobre la base de criterios de origen étnico o comunidad lingüística. No obstante, las características de descentralización que tenía la actividad anarquista, hacía mucho más evidente la persistencia de estos criterios, a través de la proliferación de periódicos publicados en diferentes idiomas. Además, a diferencia de los socialistas, casi nada los incitaba a oponerse a la sobrevivencia de la identidad étnica. Su antipoliticismo descartaba cualquier preocupación por la naturalización de los extranjeros". (Falcón, 2011: 204)

Como veremos, la diferencia entre las adscripciones étnicas de judíos y españoles o italianos, es que la judía (sea laica o religiosa) se consuma también en una identidad política, elegida y reformulada en el nuevo territorio. Si bien son conocidas para la historiografía las prácticas de asociación por parte de italianos, españoles, franceses, éstas perderán con el paso del tiempo y su institucionalización, los preceptos ideológicos en los que se fundaron. ${ }^{9}$ Ejemplos de ello son las asociaciones mutuales, las sociedades de socorros mutuos, las cooperativas de crédito, etc. Estas identidades nacionales/étnicas reflotan en tiempos de los conflicto mundiales como la Primera y la Segunda Guerra así como también con la Guerra Civil española (1936-1939).Uno de los casos que identificamos es la participación de José Grunfeld y muchos otros militantes anarquistas judíos en la Asociación Racionalista Judía desde su fundación en 1916 y a lo largo de todo el siglo $\mathrm{XX} .^{10}$

La identificación de estas familia con "lo judío" (llámese nacionalidad, país de origen o religiosidad) se entrelaza con un interés que se extiende a la mayor parte de las familias de los futuros militantes anarquistas: la educación como un bien intangible y prioritario, al mismo tiempo que las familias educan en la cultura y las lecturas que hablan de lo universal y son las más interesadas en lograr la integración a las comunidades en las que se insertan. La familia Lazarte, afincada en la ciudad de Rosario, de orígenes españoles y pertenecientes a una clase media incipiente (madre modista, padre comerciante y distribuidor) también apuestan por la educación como valor y capital incuestionable en la formación de sus hijos. ${ }^{11}$ El paso de su hijo Juan por la Escuela Racionalista de Rosario, ejemplo de las apuestas anarquistas de "alternativa" a la educación estatal y dirigida por el mismo Julio Barcos, denota un interés por parte de sus padres no en cuanto al ideario anarquista, pero si al menos racionalista y de las pedagogías que apuntan a la educación como medio para el cambio social. ${ }^{12}$ Culminó sus estudios secundarios en el Colegio Nacional de Rosario.

\footnotetext{
9 Sobre asociacionismo e inmigración: Devoto (1992); Otero (2000, 2010); Tato (2010); entre otros.

${ }^{10}$ Sobre la Asociación Racionalista Judía, ver Dujovne (2008). Bilsky, Trajtenberg y Weinstein, (1987). Mc Gee Deutsch (2010).

${ }^{11}$ Sobre la biografía y trayectoria de Juan Lazarte, remitimos a los trabajos de Ledesma Prietto (2012) y

Abad de Santillán, Invaldi y Capelletti (1964).

${ }^{12}$ Fundacionales en la reconstrucción historiográfica del tema de la educación anarquista y racionalista, son los trabajos de Dora Barrancos. Apoyada en la ciencia y el positivismo, los pilares de esta apuesta educativa son la relación entre el conocimiento (teórico) científico y el trabajo manual, al mismo tiempo que reconoce las desigualdades sociales y está orientada a los sectores populares. Existen también abordajes recientes, en
} 
Para comprender las especificidades en las biografías de las mujeres que desplegaremos en el presente artículo, es necesario referir a su origen social. Sin duda, la adscripción de estas familias a los sectores medios o en vías de ascenso social son una característica que comparten. Iris Pavón (1906-1951), hija de un maestro andaluz y cuya madre pertenecía a la clase terrateniente andaluza, crece en un ambiente letrado, y donde las prácticas políticas ligadas al socialismo de su padre y su hermano resultan en un temprano interés por parte de Iris por la justicia social y el sufrimiento de los oprimidos. ${ }^{13}$ Comienza a escribir poesía en los periódicos locales de Cruz del Eje apenas alcanzada la adolescencia y su ingreso al mundo laboral también es muy temprano.

En este sentido, la de Herminia Brumana fue una infancia a la que podríamos denominar de "clase media". Nacida en Pigüé, en 1897, su familia apuesta fuertemente por su educación y la de su hermano Florencio, logrando culminar sus estudios secundarios en tiempos en que esto agregaba un valor simbólico a un pasar económico ya consolidado. ${ }^{14}$

También italianos, los Piacenza resultan chacareros en el pueblo de Moldes, Santa Fe. Con una participación política comprometida por la causa agraria, Esteban Piacenza es referido por la bibliografía como uno de los fundadores de la Federación Agraria de la Argentina (Pagani y Perego, 1989; Archetti, 1977). En sus comienzos socialista, radical con la llegada de Irigoyen, llega a apoyar el fascismo de Mussolini en tiempos en que su hija Ana milita activamente por la causa ácrata. Un hogar cargado de debates y compromiso social en el que, según Grunfeld -quien posteriormente sería su pareja-, Ana resultó ser "la oveja negra" por sus ideas y acciones que se contraponían a las de la familia de clase media rosarina de la que esta familia formaba parte a partir de su traslado a la ciudad.

De orígenes también italianos, la familia Lunazzi se instala en La Plata y logra que su hijo José María realice los estudios primarios en la Escuela Experimental Anexa y el Colegio Nacional de La Plata, establecimientos de excelencia y vanguardia en cuanto a los contenidos educativos y los métodos de enseñanza. Además, Lunazzi crece y se forma intelectualmente en los talleres de imprenta que su familia materna poseía en la ciudad, y que eran lugar de reunión de la intelectualidad y la bohemia de la época. Los Talleres Gráficos Olivieri Domínguez resultan de gran apoyo en los años posteriores a los proyectos editoriales y de propaganda en que Lunazzi se embarca de la mano del movimiento anarquista y en los años de los debates universitarios por la Reforma Universitaria.

Hasta aquí, los escenarios en los que se emplazan las biografías discurren entre las pequeñas ciudades pampeanas. Con la excepción de quienes se afincan o llegan a Rosario, las familias reseñadas se instalan en áreas rurales o semirurales. Sus vidas transcurren aquí alejadas de los sucesos de las grandes ciudades como Buenos Aires los tres primeros lustros del siglo XX, en donde la historiografía concuerda es el momento de hegemonía del

los cuales se describen las experiencias de las escuelas racionalistas en Buenos Aires, Rosario y Bahía Blanca. Acri y Cázeres (2011); Carli (2002); Sardu (2008); Di Stefano (2005).

${ }^{13}$ Nacida en Lobería, su padre ferroviario es trasladado a Cruz del Eje y es allí donde transcurre la mayor parte de su vida, hasta su temprana muerte en 1951 a los 45 años de edad.

${ }^{14} \mathrm{Su}$ padre inmigrante emprendió con buenos resultados, distintas actividades económicas, incluso llegó a poseer campos y propiedades. Sobre Herminia Brumana, remitimos a los trabajos de Queirolo (2010) Fletcher (1987) y Samatán, (1974). 
anarquismo como ideología que moviliza sindicalmente a la mayoría de los obreros. La experiencia política previa de las familias migrantes así como el compromiso y la participación en los lugares en que se afincan representan marcas indelebles para los jóvenes que serán recién llegados en las ciudades portuarias, pujantes y conflictivas de la Argentina de los años 20. Si hay algo que caracteriza a la totalidad de las experiencias narradas, es la rápida y constante movilidad. No solamente de ascenso social por medio de un mejor pasar económico, sino por el traslado de una región, ciudad o pueblo a otros. Como veremos en los apartados siguientes, los escenarios en los que estos sujetos se emparentan con las ideas anarquistas, son más bien urbanos, pero no solo Buenos Aires. Ciudades como Rosario, Córdoba, Bahía Blanca o La Plata resultan puntos fijos en los que los actores se desplazarán en todos los años de nuestra historia. Esto no implica desconocer experiencias libertarias como la de Pampa Libre en La Pampa, o las adscripciones anarquistas de los obreros portuarios marplatenses. Lo mismo con respecto al anarquismo entre los trabajadores rurales patagónicos o los de las empresas forestales en el litoral o las uniones obreras diseminadas a lo largo y ancho de todo el país (Etchenique, 2000; Borda, 1987).

Junto a la apuesta por la escolaridad, ocurre en paralelo una socialización política temprana de la mano de las familias. Otra característica que se comparte es que son familias tradicionales, con roles de género bien diferenciados. Ninguna de las biografías reseñadas tiene cuna en lo que podría denominarse "una familia anarquista" (que en general refiere a un modelo construido desde la literatura anarquista), en donde la mujer también practica "la idea" en la crianza de los hijos, en la camaradería amorosa y con los compañeros anarquistas. (Barrancos, 1990; Bracamonte, 2006).

\section{Educación, juventud y socialización política}

Herminia Brumana se recibe de maestra normal en 1916. Al mismo tiempo que ejerce la docencia primaria en la localidad de Pigüé, emprende su trabajo literario e intelectual. Funda la revista literaria Pigĥe y comienza a relacionarse con escritores y políticos porteños quienes colaboran asiduamente con la publicación. ${ }^{15}$ Entre ellos, Juan Antonio Solari, por entonces estudiante universitario comprometido con el socialismo y el movimiento estudiantil. Herminia también participó en las publicaciones de la agrupación anarco-comunista Insurrexit, la cual pugnaba por una reforma universitaria que incluyera al mundo obrero y de los trabajadores en los claustros. ${ }^{16}$ Solari era parte del mismo grupo y, en el año 1921, se casa con Brumana y tienen su único hijo un año después.

Lunazzi, Lazarte y los Grunfeld/Grinfeld participan activamente en sus años universitarios del mismo movimiento de crítica y reforma. La Plata en los años 20 resulta la

\footnotetext{
${ }^{15}$ En estos años, Brumana participa al mismo tiempo de innumerables proyectos editoriales, diversos y algunos contrastantes. Poesía, ensayo, notas, opiniones en publicaciones políticas como La Vanguardia, La Protesta, Nuestra Tribuna, Vida Femenina,; conviven con otra en Caras y Caretas, Mundo Argentino, El Hogar, Estampa, La Novela Elegante, La Novela Semanal, y el suplemente literario de La Nación, entre muchos otros. En 1918 había publicado su primer libro de lectura: Palabritas

${ }^{16}$ Sobre Insurrexit de los años 1920-1921, ver Tarcus (2004).
} 
María E. Bordagaray, La dimensión biográfica en la configuración de los colectivos libertarios en Argentina / The biographical dimension in shaping libertarian collective in Argentina (1920-1950), Revista Izquierdas, 27, abril 2016, ISSN 0718-5049, pp. 32-62

ciudad en que confluyen muchas de estas biografías. ${ }^{17}$ Lazarte participa activamente desde Córdoba, en los años en que se instala en esa ciudad para culminar sus estudios de Medicina. ${ }^{18}$ Jacobo Maguid se traslada a La Plata a estudiar Ingeniería en el año 1925. Con una beca para costear los estudios, rápidamente socializa con el movimiento estudiantil: "En la primer asamblea de alumnos, me eligen delegado para integrar la Comisión del Centro de Estudiantes. A poco andar, vuelco en las reuniones mi pasión por una causa que conmovió al mundo: la defensa de Sacco y Vanzetti (...)”. (Jacinto cimazo, 1995: 27) Maguid funda el PUI (Partido Universitario de Izquierda) en La Plata y edita Palabras Rebeldes. Al mismo tiempo, forma parte del Grupo Ideas y trabaja por un período como editor de La Protesta. Allí comparte militancia con un joven Lunazzi, que realiza estudios en educación en la Facultad de Humanidades y realiza prácticas docentes en zonas rurales. El Grupo Ideas será la cristalización de estas militancias dispersas, ahora por primera vez organizadas en torno a una de las tendencias en que se ha dividido el movimiento anarquista de los años 20: la antorchista. ${ }^{19} \mathrm{Si}$ bien su publicación aparece hasta mediados de la década siguiente, los años 27 a 30 resultan ser las de mayor actividad y organización. Temas como la liberación sexual de las mujeres, el comunismo libertario como idea organizadora para el anarquismo, el movimiento estudiantil como eje para el futuro de las luchas anarquistas, evidencian los intereses renovados y muchas veces opuestos a los ligados a los sectores protestistas y foristas. ${ }^{20}$

Marcos Dukelsky, quien deviene en compañero de vida Iris Pavón, proveniente como Grunfeld y Maguid de una familia de inmigrantes rusos, será el director y administrador de uno de los proyectos editoriales "antorchistas", el periódico "Pampa Libre" de General Pico (La Pampa), entre abril y agosto de 1927. En estos años, José Grunfeld, se acerca al anarquismo de la mano de sus hermanos Rafael y David Grinfeld que en tiempos de la campaña por la libertad de Sacco y Vanzzetti en 1925, se encontraban desarrollando sus carreras universitarias. (Rocca, 1993) En los años subsiguientes, se relaciona con grupos libertarios de Rosario, Tres Arroyos y La Plata. Es arrestado en 1926,

17 Sobre la vida universitaria en la ciudad de La Plata, resulta iluminador el aporte de Gustavo Vallejo. Vallejo (2007).

${ }^{18}$ Una vez terminados sus estudios secundarios, Juan Lazarte se traslada a Buenos Aires a inscribirse en la carrera de Medicina, la cual abandonó, para ingresar en el Instituto del Profesorado de Buenos Aires donde se recibió de profesor en Ciencias Biológicas. Se traslada a La Plata en donde cursa estudios de antropología, paleontología, anatomía y embriología junto con Florentino Ameghino. En paralelo, sus conocimientos sobre la flora y fauna del país lo convirtien en un naturalista reconocido. Viaja a Estados Unidos en 1916, donde profundiza sus estudios en genética. Cuando ese país ingresa a la Primera Guerra Mundial, volvió y se instaló en Córdoba para culminar sus estudios de Medicina. Ledesma Prietto, Nadia (2012).

${ }^{19} \mathrm{El}$ encuentro de las vidas reseñadas con las ideas anarquistas se da en momentos en que el enfrentamiento entre las dos tendencias libertarias más importantes se manifiesta violentamente. A partir de la Revolución Rusa y del quiebre del grupo editor de La Protesta en 1915, el periódico La Antorcha se convirtió en el referente del sector en que participa la mayoría de ellos. La separación de estos dos sectores ayudó a conformar dos identidades -protestistas y antorchistas- que hacia 1924 se enfrentaron abierta y violentamente. (Anapios, 2008).

${ }^{20}$ No existen trabajos que aborden puntualmente al grupo Ideas. Es nombrada por Dora Barrancos, y aquellos estudios que abordan las luchas internas del anarquismo en los años 20. También es referido por los estudios biográficos como los de Carlos Rocca y en las autobiografías de Juan Rouco, Cimazo y Grunfeld. 
luego de ser descubierto mientras reparte folletos en un acto político en Rosario. Los tres hermanos actuaron de manera conjunta en el movimiento libertario de las décadas siguientes y tuvieron un papel protagónico en la conformación de numerosas organizaciones y proyectos culturales libertarios. Lazos familiares y de amistad son determinantes para entender el acercamiento al campo político anarquista y la posibilidad de extender en el tiempo su rol como propagandistas y referentes del anarquismo. Bernard Lahire reivindica precisamente estas variables para comprender "los grandes" desplazamientos en las biografías de las personas. La mayoría de las veces, pensar en sujetos que se desenvuelven en el campo político, lleva a minimizar cuestiones como desplazamientos o cambios en el universo familiar (por ejemplo convertirse en padre o madre, casarse, divorciarse si estaba casado) y en el universo de amistad, lo mismo que en el orden laboral y profesional (Lahire, 2004). Piacenza se encontraba en estos años realizando sus estudios de abogacía en la Universidad del Litoral, situación no muy frecuente ya que la educación universitaria todavía estaba vedada para buena parte de las mujeres. ${ }^{21}$ Sin duda, las agitaciones políticas y las causas que movilizaban al anarquismo no le eran ajenas. Es en estos años cuando conoce a José Grunfeld, ya comprometido militante anarquista y de paso por las ciudades y pueblos santafesinos. Referimos con esto a la heterogeneidad de experiencias y de situaciones que pueden acercar a los militantes con las ideas que los movilizan. A diferencia de la experiencia de Ana, Iris Pavón será madre en estos años y vuelve ya como madre sola y a cargo de su hijo a su ciudad Cruz del Eje, luego de un breve paso por la ciudad de Córdoba donde había trabajado en una concesionaria de autos. $^{22}$ Experiencias diversas, genéricamente diferenciadas, nos indican que las mujeres de esta historia transitan también trayectorias diversas para llegar a comulgar con las ideas anarquistas.

Analizando la literatura anarquista, Juan Suriano percibe que a los varones, "la idea" se les presentaba como una revelación:

La conversión al anarquismo se operaba no a través de la toma de conciencia clasista, sino mediante la revelación de la idea libertaria en un clima fuertemente emocional que representaba a un nuevo mundo moral basado en la ciencia y el progreso. (...) Los activistas portadores de estas ideas más que como organizadores actuaban como educadores, propagandistas o agitadores responsables de revelar al pueblo las bondades de la buena nueva basadas en los beneficios de la ciencia, del progreso y de la instrucción. A la vez eran considerados como verdaderos elegidos de la verdad y de la justicia. (Suriano, 2004: 94)

\footnotetext{
${ }^{21}$ No solamente las condiciones económicas de su familia le permitían seguir son sus estudios universitarios. Sin duda un interés por su propia independencia, ligada quizá a ideales cercanos al feminismo, la alejan del destino "naturalizado" para las mujeres de la época: el matrimonio y la maternidad. Sobre las mujeres, la universidad y los modelos de género ver Nari, Marcela (2004). Palermo, A. I. (2006).

22 “A los veinticuatro años, con su compañero Oscar Ramón Rojas, apodado "El Pibe", un jugador de fútbol de Cruz del Eje, tuvo a su único hijo, José Rojas, y se asumió como madre soltera desafiando a la tradicionalista sociedad cordobesa. De su hijo, quien se radicó en Córdoba, tuvo dos nietos: Oscar Ernesto y Graciela. Además, Iris adoptó a una sobrina segunda llamada Lucía Fernández. ( Guzzo, 2014)
} 
Sin embargo, para los casos que seguimos y venimos describiendo, "la idea" es una de las opciones políticas en momento de conflictos sociales y de amplia participación juvenil en las calles de las ciudades, como por ejemplo, los mítines por Sacco y Vanzzetti y la solidaridad por los presos de Bragado. Según las trayectorias analizadas, la adscripción anarquista tiene que ver más con la admiración que le despiertan las acciones callejeras motivadas por la acción represiva del Estado (al encarcelar y perseguir a los militantes sociales). La época de los "oradores brillantes" y de los "sujetos iluminados" por la idea dejan de ser el modelo del militante anarquista para ser reemplazado por el de las acciones concretas sea en las calles, en las cárceles, en la organización o en la propaganda.

Resta una reflexión final para este apartado. Primero, las biografías que seguimos ¿responden o escapan a lo esperable de acuerdo a bibliografía que nos precede y da contenido a las interpretaciones? En segundo lugar, nos preguntamos cuáles son los elementos de lo social que definen sus acciones y cuánto de ellas podría explicarse por lo derroteros individuales, familiares, de amistades o de trayectoria laborales. Sin duda sus roles como organizadores, las múltiples identidades y lazos que cada uno estableció con sus profesiones, en sus redes familiares y sus trabajos, explican una dispersión fundante y sobre la cual es necesario recalar para comprender el apartado siguiente.

\section{Luchas políticas, experiencias de vida e identificaciones}

Comenzamos este apartado proponiendo dos referencias de los propios actores sobre este período.

Durante el viaje no tengo muchos tiempos para charlas o distracciones. He traído libros que compré con 200 pesos que me dio Kaplan (editor de Nervio y después de Imán). No son textos ideológicos, sino tratados de ingeniería que repaso. Pienso en la obra de reconstrucción social que impulsan los libertarios, quizá me asignen un trabajo como técnico. (Jacinto Cimazo, 1994: 41)

Aquí, Maguid introduce sus múltiples identificaciones. Por un lado, su título de ingeniero civil obtenido en medio de detenciones, viajes, cambios de domicilio y ocupación lo habilitará, según su criterio a realizar tareas técnicas para el frente republicano español. Sin embargo, una vez llegado a la península, los altos mandos de de las organizaciones anarquistas le reservan cargos de importancia en las editoriales y órganos de propaganda.

La segunda referencia corresponde a las memorias de José Grunfeld, quien relata en pocas palabras la historia, que es su historia.

Al llegar al puerto de Buenos Aires, tras algunas paradas en Río de Janeiro, nos esperaban familiares y Anita con nuestra hijita, que por entonces tenía poco más de 6 meses...Así, sin mayores solemnidades, terminaba una etapa de actuación que comenzó el 19 de julio de 1936. Llegué a la Argentina a fines de julio. Pocos días después se declaraba el conflicto entre Inglaterra y 
Francia contra Alemania e Italia, es decir, la Segunda Guerra Mundial”. (Grunfeld, 2000:235)

Aquí se entrelazan sucesos fundamentales en el devenir del mundo contemporáneo así como también eventos que marcarán su propia vida: la derrota republicana en España, el comienzo de la Segunda Guerra Mundial y el nacimiento de su primera hija. Ambas citas dan cuenta de la interrelación que hemos identificado en las biografías entre procesos generales, estructurales, políticos y sociales y los derroteros personales, diarios, familiares y de la "vida privada". Ambos son fundamentales para comprender en profundidad las trayectorias biográficas.

El golpe militar de 1930 encuentra a Lunazzi liderando la Federación Universitaria. Logra huir a Montevideo y es recibido por Luce Fabbri, reconocida militante anarquista italiana también exiliada política junto a su padre, Luigi Fabbri. Realizará tareas docentes en todos los lugares en que se instala, aunque sea por breve tiempo. Desde 1927, en compañía de su esposa Clotilde Beaufays, realiza todo tipo de tareas asistenciales en alejados parajes de La Pampa en los que Lunazzi lleva la tarea educativa. Ella lo acompañará en sus trayectos y se encargará del cuidado de sus tres hijos: Luis, Margarita y Helena. ${ }^{23}$ De estos años datan, también, sus comienzos en la docencia universitaria de la mano del pedagogo Alfredo Calcagno.

Si bien Herminia Brumana venía participando desde su escritura en distintos proyectos editoriales anarquistas, la década del 30 la encuentra profundamente comprometida con las ideas y las organizaciones libertarias. Del mismo modo, Ana Piacenza e Iris Pavón se comprometen como propagandista de las causas anarquistas en los mismos años. La fuerte represión policial a los militantes políticos (más aún a los anarquistas) reunirá a los hermanos Grinfeld-Grunfeld, Dukelsky, Maguid y Lunazzi en la cárcel de Villa Devoto a partir de 1931. También, se encontrará allí la mayoría de los militantes libertarios (de todas las facciones y tendencias). Pero el encarcelamiento y posterior enjuiciamiento de Vuotto, Mainini y De Diago, representará el episodio a partir del cual se convoque a amplios sectores políticos (radicales, socialistas, comunistas, demócrata progresistas) y la puerta de entrada para muchas mujeres a la política. Ana Piacenza e Iris Pavón responden a esta convocatoria y, en la dinámica del proceso, irán madurando su simpatía hacia el anarquismo hasta convertirse en voces acreditadas y reconocidas por el mismo movimiento libertario.

Paradójicamente o no, es en este nuevo espacio de participación en el que tanto Iris como Ana establecerán lazos personales y afectivos con Dukelsky y Grunfeld. En el momento en que Iris conoce a Dukelsky (alrededor del año 1934), ella ya tenía su hijo resultado de una relación anterior. José Grunfeld describe en su libro el rechazo que la familia de Ana tenía por las ideas libertarias de su hija y por la relación que se establece entre ambos. Maguid describe puntillosamente de qué manera conoce a la familia Quesada y entabla relaciones con quien será su compañera de toda la vida: Juanita Quesada. Familia

\footnotetext{
${ }^{23}$ Posteriormente conocerá a quien será la madre de su cuarto hijo José Joaquín, la bióloga e investigadora Otilia Martínez Ungría.
} 
libertaria, oriunda de Bahía Blanca pero afincada en Buenos Aires, son referencia para gran parte del movimiento anarquista a lo largo del siglo $\mathrm{XX} .^{24}$

Lo cierto es que, junto al de otras mujeres, los nombres de Iris Pavón y Ana Piacenza aparecen como representantes de los Comités Pro-presos de Cruz del Eje y Rosario, respectivamente. Dukelsky representa al de Córdoba y Grunfeld acompaña a Piacenza en el de Rosario. Si bien no contamos con los discursos y conferencias realizados durante la campaña que los llevó por todo el país durante varios años, son constantes las referencias a sus actividades e intervenciones en la prensa orgánica anarquista, fundamentalmente a partir de 1935 en el periódico Acción Libertaria así como también en la prensa local y nacional. Por otro lado, es destacable el apoyo y la consideración que las mujeres de los comités de ayuda a los presos de Bragado tienen con respecto a las esposas de los mismos. Para Iris Pavón estas "mujeres de presos" son el ejemplo para otras mujeres, en cuanto sostenedoras (en lo económico y lo afectivo) de la familia, de los hijos y de sus maridos presos. Representan, en palabras de Pavón, la resistencia al avasallamiento y la incansable lucha de las mujeres de hombres militantes de "la idea". Muchas de las acciones del comité estarán dirigidas a obtener donaciones para las familias.

Mercedes Yusta Rodrigo nos brinda una serie de herramientas conceptuales para visibilizar a las mujeres y sus luchas (en su caso de estudio, contra el franquismo). Al hacer hincapié en las "pequeñas resistencias" de la vida cotidiana, llega al concepto de "mujer de preso", y con ello habilita a pensar las acciones de estas mujeres como parte de las estrategias femeninas en la lucha y la resistencia política/civil. Según la autora, las mujeres de presos,

(...) aseguraban la subsistencia cotidiana de (los presos) y a la vez tejían entre ellas redes de solidaridad que acababan convirtiéndose en redes con significación política”. (Yusta Rodrigo, 2005: 89)

Creemos relevantes estas consideraciones, fundamentalmente, porque abren el margen para el estudio de la historia de las mujeres. Por otro lado, resultan iluminadoras las apreciaciones de Mabel Bellucci sobre las características de las organizaciones de mujeres en estos tiempos:

La concurrencia cotidiana de mujeres a estos grupos informales no era demasiado numerosa ni regular (...) Los fuertes desgastes personales provocan una tendencia a la dispersión frente a las exigencias de las luchas desarrolladas dentro y fuera del hogar, la ausencia de la colaboración de sus familiares íntimos, la sobre imposición de las obligaciones domesticas con las extra-domesticas, e incluso los obstáculos permanentes presentados por otras mujeres que no alcanzan a entender la dimensión e importancia de las propuestas y operaciones existentes". (Bellucci, s/d)

\footnotetext{
${ }^{24}$ Fernando, Juanita, Nía y Menchu Quesada fundan y militan en la Federación Anarco Comunista de la argentina. Recientemente Cristina Guzzo ha abordado la familia Quesada para describir las trayectorias individuales y colectivas tanto de sus miembros como de quienes de una u otra manera se relacionaron con ellos. (Guzzo, 2014).
} 
María E. Bordagaray, La dimensión biográfica en la configuración de los colectivos libertarios en Argentina / The biographical dimension in shaping libertarian collective in Argentina (1920-1950), Revista Izquierdas, 27, abril 2016, ISSN 0718-5049, pp. 32-62

Si bien no podemos hablar sobre Iris, Herminia o Ana como ejemplos de la falta de continuidad en la militancia de las organizaciones de mujeres, sí es el caso de las demás mujeres que las acompañaban. Resulta muy dificultoso visibilizar los nombres de quienes las acompañaron y sostuvieron estos intentos organizativos de grupos de mujeres en los años 30. Sin embargo, hay otra regularidad descripta por Bellucci en la que podemos ubicar a estas mujeres: la de haber sido esposas o compañeras de otros militantes anarquistas:

El caso específico de las mujeres cuyos compañeros son militantes o adherentes al ideario anarquista, se refuerza el rol idealizado de la maternidad por su presencia activa dentro del núcleo familiar. Las razones son evidentes: la familia anarquista casi siempre esta al margen de la ley. Un libertario vive observado, perseguido y condenad@ por el orden establecido: es corrid@ de los conventillos y de los lugares laborales, pasa largos períodos en prisión, en la clandestinidad o deportad@. Esto provoca que las obligaciones mayores y menores en torno al mantenimiento material y emocional de los vástagos y de la unidad doméstica decaigan en la mujer. Ahora bien: si ella, en vez de cumplir el rol de compañera es o acompañante es también activista a la par de conyugue o camarada, la situación se complejiza por las expectativas tan altas puestas en su "noble" función de ser pieza fundamental en la unidad de la familia. (Bellucci, s/d)

Esta triple carga, la de madre, trabajadora y militante, es la que acompaña la biografía de Herminia, Iris y Ana y explica los vaivenes en sus itinerarios de acción política.

La creación de la Federación Anarco Comunista Argentina (FACA), en el año 1935, tiene a Grunfeld, Maguid, Lunazzi y Lazarte cumpliendo un rol fundacional. En este contexto, se discute por primera vez, entre otros temas, la incumbencia de crear o sostener o no grupos específicamente de mujeres y que pugnen por reivindicar aquellas cuestiones que se relacionan con el género.

Hasta este momento, Grunfeld, Lunazzi, Maguid y Lazarte son exponentes de los discursos disruptivos que se enfrentan a los instituidos por la FORA y La Protesta en el período anterior al golpe militar de 1930 y que conforman el campo político anarquista de ese momento. Sin embargo, a partir de ese momento, y por medio de un trabajo intenso cuyo fin es crear una organización para el anarquismo, se erigen como sostenedores de un nuevo discurso libertario que tiene como base el comunismo anárquico y la lucha organizada como punto de partida para el cambio social.

Es también después de 1930 que estas mujeres (Brumana, Piacenza y Pavón) se insertan en el campo político libertario aceptando, en líneas generales, las reglas impuestas por los sostenedores de estos nuevos discursos e ideas. Durante la campaña por los presos de Bragado, en la correspondencia privada que mantiene Iris Pavón con la compañera de Pascual Vuotto, se aprecia una crítica a la poca permeabilidad a la sensibilidad de la mayoría de los hombres, entre los que Vuotto representa una excepción. 
María E. Bordagaray, La dimensión biográfica en la configuración de los colectivos libertarios en Argentina / The biographical dimension in shaping libertarian collective in Argentina (1920-1950), Revista Izquierdas, 27, abril 2016, ISSN 0718-5049, pp. 32-62

La educación y el ambiente los han cerrado (a los hombres) a todo sentimiento que no sea el de dominación con respecto a la compañera. La quieren arregladita, hermoseada, aunque sea a base de artificios y de cosméticos (...). (Pavón, 1952: 45)

Este es un documento privado, y debe comprenderse en ese marco. Sin embargo, como veremos más adelante, las apuestas de Iris girarán en torno a ensalzar el rol de la madre como clave para el cambio social reforzando la idea de "igualdad" entre hombres y mujeres para lograrlo.

Herminia Brumana participa activamente en la propaganda por la actividad de los comités pro presos de Bragado, instando a las mujeres a la colaboración y el compromiso por las causas que deben movilizarlas por su "naturaleza femenina":

Insisto en lo dicho: quien no está contra la justicia, está con ella. Las mujeres de mi país que no se declaran, de viva voz o por escrito, solidarias al movimiento iniciado protestando por la condena de los presos de Bragado, se pone incondicionalmente de parte de la injusticia. ¿Con qué derecho hablarán luego de ética, de moral, de principios, quienes no han sido capaces de indignarse ante la mayor indignidad concebible? Quienes condenan a inocentes, guiados por intereses de clases, cometen un acto que rebaja la condición humana”. (Quesada, 1974: 32)

En general, su ideario contiene nociones como la responsabilidad ética individual, la maternidad como elección racional de las mujeres, el amor como un contrato racional entre dos personas que se aman y se respetan, entre otras cuestiones que hemos abordado en trabajos anteriores. (Bordagaray, 2011)

El proceso de inserción progresiva de estas mujeres en el campo libertario recién comienza en este período y se establecerá definitivamente en los años que abordaremos a continuación, los de la lucha antifascista. Hablamos del ingreso al campo político de estas mujeres en particular, lo que no quiere decir que desconozcamos que "las mujeres" participan en el escenario público y político de la Argentina y el mundo con anterioridad, incluso dentro del anarquismo. ${ }^{25}$ Así como las trayectorias señaladas en el apartado anterior explicaban el establecimiento de nuevas legitimidades en los discursos y prácticas del campo político del anarquismo por parte de los hombres, también muchas mujeres entran plenamente al campo político de la mano del interés por subvertir discursos y significados.

Tanto Iris Pavón y Marcos Dukelsky como Ana Piacenza junto a José Grunfeld, Hermina Brumana, Jacobo Maguid, Juan Lazarte y Lunazzi experimentan en esta etapa trayectos diferenciados. Ante los requerimientos de la Confederación Nacional de los Trabajadores (CNT) española y la Federación Anarquista Ibérica (FAI), la FACA tiene una participación comprometida en el proceso español entre 1936 y 1939, con varios militantes libertarios en el frente y ocupando cargos de importancia en la península. Nombra como delegados en España a Jacobo Prince, Jacobo Maguid y José Grunfeld, quienes ocuparon

\footnotetext{
${ }^{25}$ Sobre los movimientos de mujeres, la participación política de las mujeres y el movimiento feminista, remitimos al trabajo de Barrancos (2007). La misma autora ha dado cuenta de las agencias femeninas dentro del anarquismo en numerosos trabajos. Barrancos (1990 a), (1990 b), (1996).
} 
cargos de máxima responsabilidad en el diario "Solidaridad Obrera", "Tierra y Libertad" y en las respectivas organizaciones CNT y FAI., la FACA intervino en la formación de numerosos comités populares de Ayuda a España al mismo tiempo que fundó (siguiendo los criterios de la CNT y de la FAI), el Servicio de Propaganda de España e impulsó la formación de la Solidaridad Internacional Antifascista (SIA).

Iris Pavón, junto a otras mujeres, impulsa la creación de la Asociación Femenina Antiguerrera de Cruz del Eje. Éste es un grupo femenino que, si bien no responde solamente a las que comulgan con las ideas anarquistas, es impulsado por la prensa orgánica faquista “Acción Libertaria”. En su primer manifiesto, apela a un discurso que ensalza a la maternidad como estado natural de las mujeres: “(..) madres antes que mujeres; (...) como madres las llamamos y como madres las esperamos; (Pavón, 1952: 55) así también como la importancia de estas para sostener al hombre que es quien desata las verdaderas batallas contra la opresión:

Somos las compañeras, las madres, las hijas de los eternos parias que en tiempos de paz llenan los talleres y las fábricas y en tiempos de guerra los mataderos que pomposamente se llaman <gloriosos campos de batalla>. (Pavón, 1952: 55)

Se destacan las similitudes con la experiencia de las organizaciones femeninas antifascistas de España, fundamentalmente en relación al ensalzamiento de la participación política de las mujeres en clave maternal, en la politización de la maternidad como elemento distintivo de las mujeres y sus luchas contra el totalitarismo. (Yusta Rodrigo, 2011)

Según la prensa libertaria, las acciones de esta agrupación de mujeres no se limitan a recaudar fondos o a funciones de asistencia al pueblo español, sino que participa activamente (puntualmente en el caso de Cruz del Eje) en la organización de mitines y reuniones políticas junto a otras organizaciones. También actuó en el Comité de Ayuda al Pueblo español junto a Marcos Dukelsky y, de acuerdo a los registros de la SIA, fue durante un tiempo la responsable de ese organismo en la Argentina.

Siguiendo a Ana Piacenza en su actuación en España, entre 1936 y 1938, creemos importante recalar en su paso por la agrupación y publicación "Mujeres Libres", donde desarrollará una línea editorial e ideológica en pos del reconocimiento de las mujeres en su especificidad. $^{26}$ Mientras actúa allí, también será editora responsable de la publicación "Tierra y Libertad" y delegada de la FACA en el Grupo C de la FAI en Barcelona.

Si bien Grunfeld nunca se expresó críticamente a lo actuado por su compañera, las constantes omisiones a ello también deben ser tenidas en cuenta. En una serie de cartas personales disponibles para su consulta en el archivo de la Federación Libertaria de la Argentina, Grunfeld escribe a sus compañeros de la FACA en la Argentina sobre sus percepciones de la situación española, y dedica a Piacenza sólo comentarios sobre lo actuado en Tierra y Libertad. Por otro lado, ella refiere permanentemente a la importancia de la lucha política que está llevando a cabo y que la tiene como protagonista. (AAVV, 2005)

\footnotetext{
${ }^{26}$ Sobre la experiencia de la agrupación y posterior publicación "Mujeres Libres", remitimos a los siguientes trabajos: Nash (1999), Andrés Granel (2006), entre otros.
} 
Mientras tanto Juan Lazarte, instalado desde 1923 en el pueblo de San Genaro (Santa Fe), ejerce la medicina y ayuda en la formación de cooperativas de servicios para la localidad, práctica extendida entre los anarquistas con conocimientos científicos universitarios. $^{27}$ Participa como representante local de la organización internacional anarquista SIA, recaudando fondos y realizando actividades en todo el país. El gremialismo médico es otra de sus ocupaciones en este momento:

Como gremialista médico, impulsó a sus colegas a unirse ante la que él consideraba la amenaza del avance del Estado sobre su autonomía profesional y a basar sus principios profesionales dentro de lo que el consideraba la Medicina Social. (Ledesma Prietto, 2012: 76)

Comprometido desde su cotidianeidad con los ideales libertarios, es en esta década cuando nacen sus hijos y cuando publica sus principales obras. ${ }^{28}$ La liberación sexual de la mujer y la maternidad consciente y voluntaria son los ejes en los que Lazarte vincula sus conocimientos médicos con sus ideas anarquistas, temas carísimos a la militancia y a la historia del anarquismo desde sus comienzos. (Barrancos, 1990 a)

A la vuelta de España, por decisión de la FACA, Maguid se instala en la casa de Lazarte para realizar un libro sobre los sucesos de España. De esa experiencia, Maguid relata algunos elementos de su vida cotidiana:

Trabajamos en la muy nutrida biblioteca, ayudados por el fichero que su muy buena compañera ayuda a mantener al día. La casa es amplia y en el terreno del fondo, varios "bichos" conviven en armonía. Lazarte atiende en el consultorio a sus pacientes; tiene un modesto coche en que va adonde lo llamen, a visitar enfermos en las chacras cercanas, a recorrer cientos de kilómetros para intervenir como orador de fondo en actos a los que fue invitado, que a veces son dos o tres en un mismo día. (...) En la semana que convivo con él y su mujer, sus dos hijos están ausentes, estudiando". (Jacinto Cimazo, 1995: 58)

Difícilmente llegue hasta nosotros un relato similar sobre las mujeres libertarias, es decir, relatos de un observador que en tono de contemplación elogiosa observa la vida cotidiana de mujeres, como por ejemplo Brumana o Pavón. Es conocido por la historiografía de las mujeres que las acciones de aquellas que trascienden y logran ser visibilizadas por la historia se limitan a sus voces públicas, en la actividad política, en el ámbito masculino por excelencia. Es decir, pocas veces hallaremos descripciones de la vida cotidiana de las mujeres anarquistas (y de las mujeres militantes en general), en tiempos en los que la lucha política tiñe sus agencias y parece consumir los demás aspectos de sus biografías. Lo que tenemos en esos períodos en los que se retiran momentáneamente de la

\footnotetext{
${ }^{27}$ Aquiles Martínez Civelli, ingeniero mecánico y militante anarquista de la Universidad de La Plata, dedicará sus escritos y su trabajo a organizar cooperativas eléctricas en varios pueblos de la provincia de Buenos Aires. Sobre el mismo, ver Bordagaray (2012).

${ }^{28}$ Entre la prolífica obra de Lazarte, se destacan Lazarte (1932) y Lazarte (1935).
} 
arena pública, es silencio. Ese silencio esconde los cambios en la estructura familiar, separaciones, nacimientos, traslados, viajes forzados, maternidades.

José Grunfeld habla de un período de crisis familiar cuando, al momento de su regreso y el de Ana desde España, no tienen trabajo ni vivienda propia donde establecerse junto a su hija recién nacida.

Me veía frente a un panorama incierto y preocupante. Carecía de ocupación y debía asumir la responsabilidad de mantener a mi familia. Momentáneamente fui a parar a la casa de los padres de Anita: Doña Elisa Moing y don Esteban Piacenza. Fui recibido con respeto y cuidadosa consideración (...) (Grunfeld, 2000: 242)

En tiempos de penurias económicas, Grunfeld reconoce que a pesar de sus ideologías opuestas, fue posible establecer vínculos familiares amorosos, respetuosos y en donde primó la solidaridad sobre las diferencias políticas.

Don Esteban, que había sido socialista y fundador de la Federación Agraria Argentina junto con Netri, se inclinó al fascismo, erigido por un ex socialista Benito Mussolini. No obstante esta inclinación justificada por la necesidad de un ejecutivo fuerte, pasé más de un año conviviendo en su casa sin sentirme incómodo, porque en general se evitaban los comentarios políticos (...). (Grunfeld, 2000: 243)

En esta estadía junto a los Piacenza, Grunfeld descubre la problemática de los colonos santafesinos y de los arrendatarios agrícolas en general. Es a partir de esta experiencia que sus inquietudes serán expuestas ante la FACA y ésta hará suyos los reclamos y los intentos de organización en el campo. ${ }^{29}$ Por sus lazos familiares, logra también conseguir un empleo.

Maguid describe sus peripecias en la búsqueda de un trabajo estable una vez llegado de España. Si bien se instala en Santa Fe, en donde lleva adelante acciones militantes como representante de la FACA, las posibilidades laborales concretas se le presentan en Buenos Aires. Es por eso que se instala finalmente en esa ciudad.

Un excelente amigo, con quien compartí una de las pensiones estudiantiles platenses tiene una empresa y me incorpora a su oficina. Entre cálculos y controles de obra transcurren los años. (Jacinto Cimazo, 1995: 61)

De esta manera, Maguid "acomoda" su militancia y recupera lazos extendidos con anterioridad según sus necesidades laborales y de subsistencia. Una vez afincado en Capital, con su nuevo trabajo, retoma el trabajo militante. Es en este momento que conoce a su futura esposa Juanita Quesada, hermana de su amigo Fernando y con quien tiene a su única hija Alicia. Para 1943, Maguid trabaja en la Corporación de Transportes como ingeniero, puesto que sostendrá hasta su jubilación.

\footnotetext{
${ }^{29}$ Este tema ha sido abordado en Bordagaray (2011). También Ascolani (2009).
} 
María E. Bordagaray, La dimensión biográfica en la configuración de los colectivos libertarios en Argentina / The biographical dimension in shaping libertarian collective in Argentina (1920-1950), Revista Izquierdas, 27, abril 2016, ISSN 0718-5049, pp. 32-62

\section{Las biografías en los repertorios organizacionales del anarquismo}

El golpe militar de 1943, renueva la experiencia persecutoria para quienes habían experimentado la caída de la república española. También para aquellos que, sin pasar por España, sufrieron la represión y la cárcel en los primeros años de la década del 30. Grunfeld y Piacenza fueron presos en Rosario entre agosto de 1943 y octubre de 1944:

Una comisión policial invadió nuestra casa, tuvimos que acompañarlos. Nuestra hija Miri, de tres años y medio, quedó con los abuelos que tenían su residencia cerca. (...) Anita (lo supe después) fue alojada en una cárcel de mujeres administrada por monjas, donde pasó muchos meses, hasta que, por trámites del padre, le permitieron estar recluida en la casa paterna, lo que le permitió estar permanentemente con nuestra pequeña (...). (Grunfeld, 2000: 252)

Nuevamente sus lazos familiares alivian la situación a la que son conducidos por su militancia libertaria: la cárcel. Iris Pavón no correrá la misma suerte, y su hijo quedará al cuidado de su familia en Cruz del Eje. Dukelsky y Pavón fueron detenidos durante 4 meses en Córdoba, ella en la Cárcel de Mujeres del Buen Pastor. Así como estas dos parejas fueron encarceladas, cientos de militantes libertarios fueron perseguidos también.

Sin embargo, en este contexto de fuerte represión y persecución, a través del análisis de los documentos internos de la organización se aprecia gran cantidad de correspondencia entre los delegados de todos los puntos del país. Pero las vidas de los militantes anarquistas siguieron rigiéndose por las necesidades de subsistencia y los itinerarios familiares. Salido de la cárcel, Grunfeld consigue trabajo en la Biblioteca de la Facultad de Ciencias Físicomatemáticas de la Universidad del Litoral en Rosario. Lunazzi desarrolla tareas docentes y de investigación en la Facultad de Humanidades de La Plata. Lazarte continúa con sus tareas médicas y edita junto a otros la revista Nervio y Hombre de América. En paralelo, continúan las tareas organizativas en la FACA. Esta situación se resquebraja nuevamente a partir de 1946, cuando Lunazzi y Grunfeld son expulsados de sus puestos de trabajo en la universidad. Maguid retiene su puesto laboral, a expensas de ocultar su participación en el movimiento anarquista. Pero los intentos organizativos no decaen y florecen nuevas experiencias: entre marzo y junio de 1946, se crean la Unión Socialista Libertaria de Rosario, la Unión Socialista Libertaria de La Plata y la Unión Socialista Libertaria de Capital Federal. A pesar de que se presentan como agrupaciones independientes y sin ninguna relación orgánica con la FACA, los miembros fundadores de las Uniones Socialista Libertarias son históricos militantes faquistas: Ana Piacenza, Juan Lazarte José Grunfeld fundan la de Rosario, Herminia Brumana, Jacobo Maguid y muchos otros la USL de Capital Federal, David Kraiselburg, José Lunnazzi y varios más la de La Plata. ${ }^{30}$ En las actas declarativas, éstos vierten opiniones compartidas sobre la propuesta constructiva que

\footnotetext{
${ }^{30}$ La figura de David Kraiselburd, aparece permanentemente referido en las fuentes si bien no como militante activo del anarquismo, sí en empresas que sostienen y acompañan las agencias de aquellos. Fue director del diario El Día de La Plata, maestro, director e inspector de escuelas en la provincia de Buenos Aires, abogado y escritor. Entabló una amistad entrañable desde los tiempos universitarios con Lunazzi y Grunfeld.
} 
representan. (Bordagaray, 2011 b) Al mismo tiempo, aparece la Unión de Mujeres Socialistas Libertarias (UMSL) de Rosario, agrupación exclusivamente formada por mujeres, impulsada por Ana Piacenza. Los primeros meses de 1946 son el momento de la apuesta fuerte por motivar la movilización de las mujeres en clave diferenciada de la de los hombres y el escenario político que lo habilita es el debate por la sanción de los derechos políticos de las mujeres. Iris Pavón refuerza en estos años su oposición a las formaciones puramente femeninas y profundiza su idea de una maternidad liberadora de los hombres como base para la futura sociedad libre. Herminia Brumana, ahora editora y responsable de la página dedicada a la mujer en Reconstruir, habilita la pluralidad de voces que hemos identificado como contrapuestas. ${ }^{31}$

Nos interesa plasmar aquí una percepción con respecto a la figura de Herminia y su entorno en tiempos de fuerte represión y persecución política sobre sus "compañeros" de ideas. Casada con Juan Antonio Solari, nunca dejó de ejercer la docencia ni de escribir sus inquietudes en la prensa popular. A diferencia de sus compañeras, no sufre en estos años ni de la persecución o cárcel ni de apuros económicos. Su matrimonio con el dirigente socialista, su relación con los círculos culturales burgueses y su participación en la prensa popular, pudieron constituir elementos de peso para no relacionarla directamente con las organizaciones anarquistas. Por otro lado, en los años en que Piacenza y Pavón narran sus desventuras carcelarias, Brumana relata sus viajes por Estados Unidos en compañía de su esposo y describe las bondades de la vida de las mujeres norteamericana en cuanto a la vida social y el cuidado compartido de sus hijos en manos de las baby sitter. (Reconstruir, $\mathrm{N}^{\circ} 4$, 1946) Es decir, el entorno desde el cual escriben es diametralmente opuesto. Brumana es una figura pública, reconocida en los ambientes literarios e intelectuales, así como también en la docencia y por la prensa masiva gracias a sus continuas escrituras. Pavón y Piacenza serán reconocidas en la posterioridad, de la mano de las acciones reivindicativas de grupos feministas que ven en estas mujeres ejemplos de lucha y resistencia.

En otro orden de cosas, así como no todas las mujeres libertarias perciben de la misma manera el rol de las mujeres en la lucha política y sus significados, el envejecimiento en las trayectorias nos permite ver también el viraje en los repertorios discursivos, pasando de un lugar "innovador" y disruptivo en relación al hegemónico en el campo, hacia uno conservador y concordante con el sostenido por los dominantes del mismo campo político anarquista. Es en ese momento cuando quienes actúan nucleados en la FACA replantean sus estrategias de acción política orientando sus apuestas hacia el fortalecimiento de los grupos ya comprometidos con el ideario libertario y abandonando los intentos por ampliar la convocatoria hacia todos los sectores que se oponen al peronismofascismo. Y es allí, también, cuando la apelación a las mujeres desde una perspectiva que contempla los intereses de ellas como tales y acercándose a una perspectiva liberadora cercana al feminismo, es suplantada por otra mucho más conservadora en cuanto al rol de la mujer y su lugar en la lucha social y política. Herminia fallece de cáncer en el año 1954. Iris luego de una larga enfermedad renal, muere en 1951. No hemos hallado rastros de escritos o militancia libertaria por parte de Ana con posterioridad a 1951, aunque fallece en

${ }^{31}$ Por ejemplo, el trabajo de Scarzanella (2009). 
María E. Bordagaray, La dimensión biográfica en la configuración de los colectivos libertarios en Argentina / The biographical dimension in shaping libertarian collective in Argentina (1920-1950), Revista Izquierdas, 27, abril 2016, ISSN 0718-5049, pp. 32-62

1972. Los hombres sobreviven ampliamente al período estudiado y sus actividades siguen bifurcándose por caminos heterogéneos, pero siempre ligados a la militancia por "la idea".

Resta una mención sobre algunas personas que, en tiempos del peronismo, aparecen organizando y sosteniendo los "frentes" de disputa abiertos por el anarquismo. Entre las mujeres, Concepción Fernández (alias Andrea Zumarán) escribe en la página cultural de Reconstruir. Según consigna Guzzo,

Militante anarquista, escritora, poeta. Hija de inmigrantes españoles de Galicia, llegó a la Argentina siendo muy pequeña, aunque se desconocen las fechas de su nacimiento y arribo al país. Comenzó a trabajar como planchadora pero luego adoptó la profesión de librera a domicilio. (...) Actuó en el ambiente editorial e intelectual de las décadas de 1920 y 1930. Como militante anarcofeminista colaboró asiduamente en La Protesta, Acción Libertaria y Reconstruir utilizando el seudónimo de Adriana Zumarán (nombre de la novela de Carlos Alberto Leumann). También colaboró en el quincenario antimilitarista Bandera Negra". (Guzzo, 2014: 67)

Otras mujeres como Emilia Goyena y Diana Manso también participan en Reconstruir en estos años. Carecemos de datos biográficos sobre ellas.

Entre los hombres, merecen una mención las figuras de Luis Danussi y Floreal Ferrara: el primero abocado a la causa obrera; el segundo, al movimiento estudiantil universitario. Las referencias a Danussi comienzan para nosotros con la mención de sus compañeros Jacinto Cimazo y José Grunfeld, quienes le dedicaron un libro biográfico, en el que también recopilan testimonios de otros compañeros sobre su persona. ${ }^{32}$ Cimazo y Grunfeld, 1981) Nacido en Bahía Blanca, en 1913, crece en una familia de inmigrantes italianos en los que la lectura y la crítica al sistema imperante eran constantes. Empleado en el taller metalúrgico de sus dos hermanos mayores, vive en la ciudad ya agitada de fines de los años 20, en que las disputas y los discursos callejeros convertían los domingos pueblerinos en mitines políticos y tribuna de ideas contestatarias. ${ }^{33}$ Perseguido luego del golpe de Uriburu por sus actividades sindicales y en sintonía con el grupo "antorchista" dentro de las tendencias libertarias, se instala en Rosario. Vuelve a Bahía Blanca actuando en la solidaridad con España y miembro de la recién fundada FACA. Nuevamente, huirá siendo perseguido por sus actividades de propagandista de la causa republicana. En Buenos Aires, junto a su amigo y coterráneo Fernando Quesada, organiza la parte técnica del Servicio de Propaganda España, editando la revista Documentos Históricos de España. Participa ininterrumpidamente en el gremialismo gráfico, desde su ingreso en los talleres Estampa en 1939. Escribe y dirige varias publicaciones como Acción Libertaria, Reconstruir, Solidaridad Obrera, hombre de América y El Obrero Gráfico. Fue detenido en tiempos del peronismo y retoma la actividad sindical una vez derrocado el régimen. A lo largo de su trayectoria, seguramente limitada por las cuestiones familiares y laborales que hemos identificado en este capítulo para los/las militantes libertarios, puso énfasis en el

\footnotetext{
${ }^{32}$ Otros trabajos que nombran a Danussi son López Trujillo (2005), Tarcus (2006). Contreras (s/d) Ceruso (2012).

${ }^{33}$ Sobre el juego callejero en la década del 20, ver González Aleman (2012).
} 
trabajo de construcción sindical, en el mundo del trabajo y en la educación de estos mismos sectores. Muere en Buenos Aires1978.

Por último, citamos a Floreal Ferrara, quien es referido por las publicaciones Revista Americana de Educación, Acción Libertaria y Reconstruir como ejemplo del joven militante anarquista actuante en el anarquismo en tiempos de resistencia al peronismo. Puntualmente en Reconstruir, aparece su nombre y apellido como corresponsal responsable de narrar los sucesos diarios de la cuestión universitaria en La Plata. En ese momento, estudia la carrera de Medicina en la universidad local y milita en su centro de estudiantes. También realiza reportajes a importantes figuras del anarquismo local. Sin embargo, su figura se pierde de vista en la prensa libertaria alrededor de 1948. Sobre Floreal Ferrara, Svampa ha escrito:

Médico sanitarista de larga trayectoria, que se reconoce como discípulo de Ramón Carrillo; peronista de toda la vida, con una indudable vocación libertaria; hombre ligado históricamente a los sindicatos, muy especialmente a partir del período de la resistencia peronista; Ferrara fue también dos veces Ministro de salud en la provincia de Buenos Aires, bajo las gobernaciones de Oscar Bidegain (entre 1973-1974), y Antonio Cafiero (entre 1987-1988). (Svampa, 2010: 7)

Es de nuestro interés evocar esta figura puesto que las fuentes anarquistas hablan de él como uno de sus más comprometidos militantes. Sin embargo, como él lo narra en la entrevista citada, luego de 1951, comienza a mirar al peronismo con otros ojos. Nacido en Punta Alta, en 1923, hijo de un viejo militante anarquista de origen yugoslavo y excelente alumno, se traslada a La Plata, donde se recibe en el año 1950. En estos años abandona las filas anarquistas, ya ejerciendo la profesión médica conoce a Ramón Carrillo y su obra. Explica de esta manera su incondicional apoyo a Perón:

Yo siempre dije que instalar doscientos treinta hospitales, sesenta mil camas más de las que teníamos, eso es una revolución. Y a esa revolución yo la llamé "la revolución de la capacidad instalada", porque era auténticamente producir una gran revolución en el país. No solamente porque produce una revolución en la atención de los enfermos, de los enfermos comunes; sino que hace una revolución en los enfermos mentales, él es el creador de grandes hospitales, enormes... con enorme significación". (Svampa, 2010: 31)

A partir de allí, Ferrara resultará una figura ineludible para quienes evocan la obra sanitaria y de atención primaria salud en los sucesivos gobiernos peronistas. Para nuestro trabajo, la militancia de Ferrara es visibilizada en torno a su experiencia de militancia estudiantil. 
María E. Bordagaray, La dimensión biográfica en la configuración de los colectivos libertarios en Argentina / The biographical dimension in shaping libertarian collective in Argentina (1920-1950), Revista Izquierdas, 27, abril 2016, ISSN 0718-5049, pp. 32-62

\section{Consideraciones finales}

El objetivo de este capítulo fue transitar en la diversidad de las trayectorias biográficas libertarias. Según refiere Latour:

Así como los actores constantemente son llevados a participar en la formación y destrucción de grupos (...) también se dedican a proveer explicaciones polémicas, de sus acciones así como de las de los demás. Cada entrevista, narración y comentario, por trivial que parezca, proveerá al analista un conjunto desconcertante de entidades para dar cuenta de los cómo y los por qué de cualquier curso de acción. Los científicos sociales se quedarán dormidos mucho antes de que los actores dejen de inundarlos de datos". (Latour, 2008: 75)

Desde ese punto de partida, nuestro primer acercamiento a estos "nombres", a estos sujetos/actores, parte de haber focalizado en los agrupamientos u organizaciones políticas del movimiento anarquista. Es decir, la identificación de cada una de estas individualidades, proviene de haberlas observado en primer lugar en su rol/identificación con las ideas libertarias. A partir de allí, nuestro recorrido pivotea entre las agencias individuales y colectivas, puesto que nuestro eje como observadores se establece en la participación de estos actores dentro de los colectivos libertarios. Es decir, nuestra mirada se aleja de la etnografía para recuperar (recortar) la gran cantidad de "datos" que ellos nos brindan a partir del registro de sus propias voces y/o acciones. Sin embargo, creemos que la individualización y la visibilidad que le hemos dado a ciertos nombres dentro de esos colectivos, resulta uno de los aportes más importantes del presente artículo. Por otro lado, las particularidades en las experiencias tanto de los hombres como de las mujeres que sostuvieron este amplio abanico de estrategias de acción política, contribuyen a clarifica y echar luz sobre un período de la historia que resulta oscura en relación a las agencias ácratas. Es decir, no sólo hemos recuperado nombre, personas, sino también grupos, dinámicas y estrategias colectivas que contienen y se construyen en base (pero no solamente) a esas estrategias individuales. Sin duda sus roles como organizadores, las múltiples identidades y lazos que cada uno estableció con sus profesiones, en sus redes familiares y sus trabajos, explican una dispersión fundante y sobre la cual es necesario recalar para comprender el apartado siguiente.

Sin abandonar definitivamente las perspectivas bourdieuanas, al fin y al cabo, a lo largo de nuestro recorrido hemos visibilizado las posiciones que las y los libertarios han ocupado en el campo político del anarquismo argentino. Podemos esbozar que tanto Ana Piacenza como Iris Pavón y Herminia Brumana, han participado en estos espacios siempre desde un lugar subordinado al de los hombres. Sin embargo, los recorridos biográficos dan cuenta de que esta subordinación no es homogénea, y en general se relaciona con las experiencias, identificaciones y eventualidades que cada una de ellas contienen en sus biografías. El capital social, cultural, profesional, pero también sus relaciones personales, sus familias y lugares de origen, las posibilidades laborales, la cárcel o el nacimiento de los hijos, son variables que definen directamente el posicionamiento tanto de los hombres como de las mujeres en ese campo político, el del anarquismo de los años 30/40.

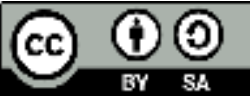


María E. Bordagaray, La dimensión biográfica en la configuración de los colectivos libertarios en Argentina / The biographical dimension in shaping libertarian collective in Argentina (1920-1950), Revista Izquierdas, 27, abril 2016, ISSN 0718-5049, pp. 32-62

Estas variables, aparentemente "secundarias" para el estudio de un movimiento político o de una biografía de un militante, resultan indispensables para abordar las vidas de aquellas que como Iris Pavón y Ana Piacenza han sido ignoradas por los relatos historiográficos y por su propio movimiento. Como ya lo adelantamos, Iris Pavón muere en el año 1951 y Ana Piacenza comienza a alejarse de su militancia libertaria durante los años peronistas. Grunfeld, Maguid y Lunazzi participarán activamente en él hasta bien entrados los años 90 sin perder su posición dominante ni su rol organizador. La lectura desde estas perspectivas nos permite visibilizar estas particularidades, que en definitiva y como hemos demostrado en el presente artículo, son las que definen las posibilidades de la acción militante por las ideas libertarias.

\section{Referencias bibliográficas}

- AAVV (2005). Catálogo de publicaciones anarquistas, s/d.

- Abad de Santillán, Diego (1930). El movimiento anarquista en la Argentina. Buenos Aires: Argonauta. Marotta, S. (1960). El movimiento sindical argentino: su génesis y desarrollo (Vol. 1). Ediciones" Lacio,".

- Abad de Santillán, Diego, Invaldi, Ángel y Capelletti, Ángel (1964). Juan Lazarte, militante social, médico, humanista. Rosario, Grupo Editor de Estudios Sociales.

- Acha, Omar (2009), Historia crítica de la historiografía argentina: las izquierdas en el siglo $X X$, vol. 1. Buenos Aires: Prometeo.

- Acri, Martín A. y Cázeres María del C. (2011). La educación libertaria en la Argentina y en México. 1861-1945. Libros de Anarres, Buenos Aires.

- Anapios, Luciana (2008) "Compañeros, adversarios y enemigos. Conflictos internos en el anarquismo argentino en la década del '20", en Entrepasados, № 31.

- Anapios, Luciana (2011). "Una promesa de folletos. El rol de la prensa en el movimiento anarquista en la Argentina (1890-1930)", en A contracorriente. Una revista de historia social y literatura en América Latina. Vol. 8, No. 2, Winter. www.ncsu.edu/project/acontracorriente.

- Andrés Granel, Elena (2006). "Mujeres Libres: emancipación femenina y revolución social", en Germinal. Revista de Estudios libertarios, № 2 .

- Archetti, Eduardo (1977). "El proceso de capitalización de campesinos argentinos", en Cahiers du monde hispanique et luso-brésilien, 28(1), 123-140.

- Avni, Haim (1986) La inmigración judía en la Argentina. Buenos Aires, Editorial AMIA.

- Barrancos, Dora (1990a). Anarquismo, educación y costumbres en la Argentina de principios de siglo, Buenos Aires, Contrapunto.

- Barrancos, Dora (1990 b). "Anarquismo y sexualidad"; en Armus, Diego (comp). Mundo urbano y cultura popular. Buenos Aires, Sudamericana.

- Barrancos, Dora (1996) "Mujeres de Nuestra Tribuna: el difícil oficio de la diferencia", en Mora. Revista del Área Interdisciplinaria de Estudios de la Mujer, $\mathrm{N}^{\circ}$ 2. UBA, Buenos Aires.

- Barrancos, Dora (2007). Mujeres en la Sociedad Argentina. Una historia de cinco siglos. Buenos Aires, Sudamericana.

- Barrancos, Dora (2008). Mujeres, entre la casa y la plaza. Buenos Aires, Sudamericana.

- Barrandeguy, Emma (1997). Salvadora. Una mujer de Crítica. Buenos Aires, Vinciguerra.

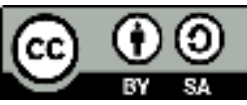


María E. Bordagaray, La dimensión biográfica en la configuración de los colectivos libertarios en Argentina / The biographical dimension in shaping libertarian collective in Argentina (1920-1950), Revista Izquierdas, 27, abril 2016, ISSN 0718-5049, pp. 32-62

- Bayer, Osvaldo (1970). Severino Di Giovanni, el idealista de la violencia. Buenos Aires, Editorial Galerna.

- Bayer, Osvaldo (2007). Los anarquistas expropiadores y otros ensayos. Buenos Aires, Planeta.

- Bayer, Osvaldo (2007) "La influencia de la inmigración italiana en el movimiento anarquista argentino", en Los anarquistas expropiadores y otros ensayos. . .

- Bellucci, Mabel (s/d) "Anarquismo y feminismo: el movimiento de mujeres anarquistas con sus logros y desafíos hacia principios de siglo http://www.nodo50.org/mujerescreativas/mabel_bellucci.htm

- Bjerg, María (2009). Historias de la inmigración en la Argentina. Buenos Aires, Edhasa.

- Borda, Ángel (1987). Perfil de un libertario. Cuentos, narraciones y poesías del litoral. Historia Sindical de Entre Ríos. Buenos Aires, Editorial Reconstruir.

- Bordagaray, María Eugenia (2011a) "La anarquistas argentinas y el voto femenino (19461955), en Barry, Carolina (comp.). Sufragio femenino. Prácticas y debates políticos, religiosos y culturales en Argentina y América Latina. Buenos Aires, EDUNTRF.

- Bordagaray, María Eugenia (2011b). "Anarquismo en la Argentina. Repertorios organizacionales y de acción colectiva en el movimiento libertario, 1935-1955", en Repertorio Americano, Segunda Nueva Época, volumen 21, Costa Rica, octubre.

- Bordagaray, María Eugenia (2012). "Anarquismo y movimiento universitario en Argentina, 1935-1950" Revista CS, №. Universidad de Cali.

- Bordagaray, María Eugenia (2014). Controversias libertarias: la interpelación anarquista en tiempos del peronismo.Tesis de doctorado. Facultad de Humanidades y Ciencias de la Educación, Universidad Nacional de La Plata. En http://sedici.unlp.edu.ar/handle/10915/44269

- Bourdieu, Pierre (1991). "Estructuras, habitus, prácticas", en El sentido práctico, Madrid, Taurus.

- Bourdieu, Pierre (2005). "La ilusión biográfica" en Archipiélago: Cuadernos de crítica de la cultura, $\mathrm{N}^{\mathrm{o}} 69,87-96$.

- Calzetta, Elsa (2005). Nuestra tribuna: Hojita sentir anárquico femenino, 1922-1925. Editorial de la Universidad Nacional del Sur.

- Camarero, H. (2005) "La izquierda como objeto historiográfico. Un balance de los estudios sobre el socialismo y el comunismo en la Argentina", en Nuevo Topo. Revista de historia y pensamiento crítico. $\mathrm{N}^{\mathrm{o}} 1$.

- Capelleti, Angel (1990). El anarquismo en América Latina. C. M. Rama (Ed.). Fundación Biblioteca Ayacucho.

- Ceruso, Diego (2012). "La izquierda y la organización sindical en el lugar de trabajo, 19201940", en Revista Archivos del Historia del Movimiento Obrero y la Izquierda, № 1.

- Cesano, José Daniel (2010). Inmigración, anarquismo y sistema penal. Los discursos expertos y la prensa Córdoba y Buenos Aires 1890 - 1910 (Protesta social, flujos migratorios y criminalización). Buenos Aires, Editorial Alción.

- De la Rosa, María Fernanda (2012). Diego Abad de Santillán. Una utopía en rojo y negro. Editorial Académica Española.

- Del Campo, Hugo (1971). Los anarquistas, Buenos Aires, Centro Editor de América Latina.

- Delgado, Josefina (2005). Salvadora. La dueña del diario Crítica. Buenos Aires, Sudamericana.

- Devoto, Fernando (1992). Asociacionismo, trabajo e identidad étnica: Los italianos en América Latina en una perspectiva comparada. Cemla-Cser-Iehs. 
María E. Bordagaray, La dimensión biográfica en la configuración de los colectivos libertarios en Argentina / The biographical dimension in shaping libertarian collective in Argentina (1920-1950), Revista Izquierdas, 27, abril 2016, ISSN 0718-5049, pp. 32-62

- Devoto, Fernando (2003). Historia de la inmigración en la Argentina. Buenos Aires, Sudamericana.

- Di Stefano, M. (2005). "Políticas de lectura y escritura en las escuelas del anarquismo en la Argentina a principios del siglo XX. Cuadernos del Sur. Letras," (3536), 75-95.

- Dujovne, Alicia (2008). "Cartografía de las publicaciones periódicas judías de izquierda en Argentina, 1900-1953”, en Revista del Museo de Antropología, 1, 121-138.

- Etchenique, Jorge (2000). Pampa Libre. Anarquistas en la pampa argentina. Amerindia/Universidad Nacional de Quilmes.

- Fagoaga, Concha (1985). La voz y el voto de las mujeres. El sufragismo en España, Barcelona, Icaria.

- Falcón, Ricardo (2011). "Izquierdas, régimen político, cuestión étnica y cuestión social en Argentina (1890-1912)", en Estudios Sociales, 40 (1).

- Fletcher, Lea (1987). Una mujer llamada Herminia, Buenos Aires, Catálogos.

- González Aleman, Marianne (2012) "El conflicto callejero y el derecho de reunión en Buenos Aires durante la segunda presidencia de Irigoyen" en POLHIS, Año 5, No 9.

- Graciano, Osvaldo (2008) Entre la torre de marfil y el compromiso político. Intelectuales de izquierda en la Argentina 1918-1955. Quilmes, Universidad Nacional de Quilmes.

- Grunfeld, José y Jacinto Cimazo (1981). Luis Danussi, en el movimiento social y obrero argentino. 1938-1978. Buenos Aires, Proyección.

- Grunfeld, José (2000). Memorias de un anarquista. Buenos Aires, Nuevo Hacer.

- Guzzo, Cristina (2003). Las anarquistas rioplatenses. 1890-1990. Phoenix, Orbis Press. Saítta, Sylvia (2006) "Prólogo", en Las descentradas. Buenos Aires, Tantalia.

- Guzzo, Cristina (2014). Libertarias en América del Sur. De la A a la Z. Buenos Aires, Libros de Anarres.

- Hernun (2003) En torno a la anarquía. Sitio web: http://entornoalaanarquia.com.ar/versionhtml/enta13.htm. Visitado por última vez $11 / 06 / 2014$.

- Marti, Alejandro (2010) Simón Radowitzky. Del atentado a Falcón a la Guerra Civil Española. De la Campana.

- Lahire, Bernard (2004) El Hombre Plural. Los resortes de la acción. Barcelona, Bellaterra.

- Latour, Bruno (2008). Reensamblar lo social: una introducción a la teoría del actor-red. Buenos Aires, Manantial.

- Lazarte, Juan (1932). Revolución sexual de Nuestro Tiempo. Buenos Aires, Nervio.

- Lazarte, Juan (1935). Sociedad y prostitución. Rosario, Librería Ruiz.

- Lazarte, Juan (1936). Contralor de los nacimientos. Rosario, Librería Ruiz.

- Ledesma Prietto, Nadia (2012 a) "Revisando la categoría de intelectual para el anarquismo posterior a 1930. Un estudio de caso a través de Juan Lazarte, 1918- 1963”, en Pasado porvenir; Lugar: Trelew, provincia de Chubut; Vol 6.

- Ledesma Prietto, Nadia (2012 b). "Apuntes sobre la eugenesia y la libertad sexual en el discurso de dos médicos anarquistas. Argentina, 1930-1940", en Nomadías, $\mathrm{N}^{\circ} 16$.

- Ledesma Prietto, Nadia y Manzoni, Gisela (2010). "Pluma, Aguja y Barricadas: desafiando la hegemonía patriarcal”, en Valobra, Adriana (edit.) Mujeres en espacios bonaerenses. La Plata, EDULP.

- López Trujillo, Fernando (2005). Vidas en Rojo y negro. Una historia del anarquismo en la Década Infame. La Plata, Letra Libre.

- Mc Gee Deutsch, S. (2010). Crossing Borders, Claiming a Nation: A History of Argentine Jewish Women, 1880-1955, op. cit. 
María E. Bordagaray, La dimensión biográfica en la configuración de los colectivos libertarios en Argentina / The biographical dimension in shaping libertarian collective in Argentina (1920-1950), Revista Izquierdas, 27, abril 2016, ISSN 0718-5049, pp. 32-62

- Miraux, Jean Philipe (2005). La autobiografía. La escritura del yo. Buenos Aires, Nueva Visión

- Nash, Mary (1999). Rojas. Las mujeres republicanas en la Guerra Civil, Madrid, Taurus.

- Otero, Hernán (2000). "Endogamia e integración de inmigrantes en la Argentina moderna. Balances y perspectivas desde un enfoque regional." Seminario sobre Población y Sociedad en América Latina, comp. Boleda and Mercado (Salta, Argentina, 2000).

- Otero, Hernán (2010). "El asociacionismo francés en la Argentina. Una perspectiva secular.", en EIAL: Estudios Interdisciplinarios de America Latina y el Caribe, 21(2).

- Oved, Iaacov (1991) "Influencia del anarquismo español sobre la formación del anarquismo argentino", en Revista estudios Interdisciplinarios de América Latina y el Caribe, Vol 2.1. S/nPagani, R. y Perego, E. (1989). La cuestión agraria en 1919: chacareros y terratenientes (Vol. 8). Centro Editor de América Latina.

- Palermo, A. I. (2006). "El acceso de las mujeres a la educación universitaria. Revista argentina de sociología", 4 (7), 11-46.

- Pavón, Iris Teresa (1952). Pasión de Justicia, Buenos Aires, Editorial Reconstruir.

- Queirolo, Graciela (2010 a) "Herminia C. Brumana. La maternidad social a través del magisterio y de la escritura", en Adriana Valobra (ed.), Mujeres en espacios bonaerenses, Buenos Aires, EDULP.

- Quesada, Fernando (1974). El Proceso de Bragado. Buenos Aires, Editorial Korrigan.

- Recosntruir, No 4, Agosto de 1946.

- Rocca, Carlos (1983) El Dr. Rafael Grinfeld o el precio de investigación científica en la Argentina, Eds. Geocart S.A., Buenos Aires.

- Rocca, Carlos José (1998). José María Lunazzi. Semblanza de un Socialista Libertario. Editorial Universitaria de LA Plata.

- Rouco Buela, Juana (1964). Historia de un ideal vivido por una mujer. s/d

- Saitta, Sylvia (1995) "Anarquismo, teosofía y sexualidad: Salvadora Medina Onrubia" en Mora, Revista del Area Interdisciplinaria de Estudios de la Mujer, Facultad de Filosofía y Letras, Universidad de Buenos Aires, $\mathrm{n}^{\circ} 1$.

- Saítta, Sylvia (1998). Regueros de tinta. El diario Crítica en la década de 1920, Buenos Aires, Sudamericana. Fletcher, Lea (1987) Una mujer llamada Herminia, Buenos Aires, Catálogos.

- Samatán, Marta (1974). Herminia Brumana, la rebelde. Buenos Aires, Plus Ultra.

- Sardu, A. (2008). "Una molesta piedra en el camino: Educación Anarquista", en Theomai: estudios sobre sociedad, naturaleza y desarrollo, (17), 11. 220.

- Sarlo, Beatriz (2001). La batalla de las ideas, Buenos Aires, Editorial Ariel.

- Scarzanella, Eugenia (2009). "Mujeres y producción/consumo cultural en la Argentina peronista: las revistas de la editorial Abril", en Anuario de hojas de Warmi, $\mathrm{N}^{\mathrm{o}} 14$.

- Suriano, Juán (2001). Anarquistas: cultura y política libertaria en Buenos Aires, 18901910. Buenos Aires, Manantial.

- Svampa, Maritella (2010). Certezas, incertezas y desmesuras de un pensamiento político: conversaciones con Floreal Ferrara. Buenos Aires, Biblioteca Nacional.

- Tarcus, Horacio (2004 b). "Revistas, intelectuales y formaciones culturales izquierdistas en la Argentina de los 20", en Revista iberoamericana, 70(208), 749-772.

- Tarcus, Horacio (2007). Diccionario biográfico de la izquierda argentina: de los anarquistas a la" nueva izquierda" 1870-1976. Buenos Aires, Emece Editores

- Tato, María Inés (2010). "En el nombre de la Patria: asociacionismo y nacionalismo en la Argentina en torno de la Primera Guerra Mundial.", en AAVV. 200 años de Iberoamérica (1810-2010), 303-315. 
María E. Bordagaray, La dimensión biográfica en la configuración de los colectivos libertarios en Argentina / The biographical dimension in shaping libertarian collective in Argentina (1920-1950), Revista Izquierdas, 27, abril 2016, ISSN 0718-5049, pp. 32-62

- Vallejo, Gustavo (2007). Escenarios de la cultura científica argentina. Ciudad y Universidad (1882-1955). Madrid, Consejo Superior de Investigaciones Científicas.

- Yusta Rodrigo, Mercedes (2005). "Las mujeres en la resistencia antifranquista, un estado de la cuestión”, en Arenal Revista de Historia de las Mujeres, $\mathrm{N}^{\circ}$ 12. enero-junio.

- Yusta Rodrigo, Mercedes (2011). "La construcción de una cultura política femenina desde el antifascismo (1934-1950)", en Aguado, Ana y Ortega, teresa (dir.). Feminismos y antifeminismos. Culturas políticas e identidades de género en la España del Siglo XX. Valencia, PUV.

- Zaragoza Rovira, Gonzalo (1996). Anarquismo argentino, 1876-1902. Medir, Ediciones de la Torre. 